\title{
PACIFIZMO REFLEKSIJA TARPUKARIO LIETUVOJE (XX A. 3-4 DEŠ.)
}

\author{
Dr. Modestas Kuodys \\ Kauno IX forto muziejus
}

\section{IVADAS}

Šiandieninès komplikuotos geopolitinès situacijos akivaizdoje Lietuvos Respublikai stiprinant savo ginkluotąsias pajègas, visuomenèje neretai pasigirsta šiam procesui prieštaraujančių balsų, abejojama mažos valstybės galimybėmis apsiginti, neigiamas pats grèsmès egzistavimas arba apskritai idealistiškai smerkiamos bet kokios prievartos ir „militarizmo“ apraiškos. Tokios retorikos motyvai gali būti ịvairūs - nuoširdūs arba inspiruoti užsakymo, tačiau pačia bendriausia prasme ji laikytina pacifistinio požiūrio išraiška. Panaršius internete susidaro ịspūdis, jog šiuolaikiniam žmogui pacifizmas dažniausiai asocijuojasi su tam tikrais nesmurtinị protestą atspindinčiais populiariosios kultūros (pirmiausia - muzikinio jos dèmens) simboliais, gimusiais XX a. 7-ajame ir 8-ajame dešimtmetyje ir glaudžiai susijusiais su Vakarų pasaulio realijomis: pasipriešinimo Vietnamo karui (1965-1975 m.) Jungtinèse Amerikos Valstijose (JAV) akcijomis ${ }^{1}$, studentų demonstracijomis laisvojoje Europoje, hipių gyvenimo būdu². Tačiau iš tiesų to, ką abstrakčiai galètume pavadinti pacifistinèmis nuostatomis, istorinès šaknys glūdi kur kas giliau ir yra gerokai senesnès už patị terminą ${ }^{3}$. Politinių ir socialinių teorijų tyrejjai jas užčiuopia jau

1 Šis judejimas prieš karą Vietname kartu su kova už juodaodžių pilietines teises buvo bene labiausiai XX amžiuje JAV visuomenę sujudinęs ir supriešinęs procesas: Baringer M., Antiwar movement U.S // The Encyclopedia of the Vietnam War, Vol. 1, second. ed., edited by S. C. Tucker, Santa Barbara: ABC CLIO, 2011, p. 53-55.

2 Alvah D., Antiwar protests, Non-U.S // ten pat, p. 55-57.

3 Žodis „pacifizmas“, kurio autoriumi yra laikomas prancūzas Emilis Arno (E. Arnaud) Ł̇ mokslo ir žiniasklaidos apyvartą pateko po $1901 \mathrm{~m}$. Didžiosios Britanijos Glazgo mieste ịvykusio tarptautinio taikos kongreso. Tačiau labiausiai terminą išgarsino kitas prancūzų 
antikinèje Graikijoje $e^{4}$, nors dažniau linkstama „atsispirti“ nuo šventojo Augustino (354-430 m.) mokymo apie teisingą karą ${ }^{5}$. Vèlesnèse epochose autoritetų, reprezentavusių ir interpretavusių taikos idejją, radosi kur kas daugiau. Reformacijos procesui ir religiniams karams Europoje besibaigiant (XVII a.), atsirado savitų krikščioniškų religinių srovių (menonitai, kvakeriai ir kt.), savo etines normas grindusių atsisakymo prievartos ir pagarbos gyvybei principais. Tarp šios rūšies pacifistų labiausiai pagarsèjo kvakeriai (angl. quakers), ypač kai jų bendruomenė išsiplètè ir sutvirtejo persikèlusi iš Britanijos ị rytinę Šiaurès Amerikos pakrantę (Naująą Angliją) $)^{6}$. Vis dèlto ši ir kitos, vèliau susiformavusios, panašios religinès bendruomenès tolesnei pasaulietinio pacifizmo raidai neturejjo didesnès itakos ${ }^{7}$, todèl istorikų yra nagrinejjamos kaip atskiras objektas.

Pirmuoju mąstytoju, moderniųjų laikų aušroje iškèlusiu žmonijos taikaus sambūvio viziją, paprastai yra laikomas XVII a. Nyderlanduose gy-

mąstytojas - Emilis Fago (E. Faguet), parašęs knygą „Le Pacifisme“ (išleista 1908 m.): Van den Dungen P., Pacifism: Sources of Inspiration and Motivation // West European Pacifism and the Strategy for Peace, ed., P. van den Dungen, New York: Palgrave Macmillan, 1985, p. 19-20.

4 Dawson D., Militarism and Morality in the Ancient World, Boulder: Westview Press, 1996, p. 65-66.

5 Cady D. L., From Warism to Pacifism: A Moral Continium, second ed, Philadelphia: Temple University Press, 2010, p. 7.

6 Išsamiai apie juos: Baldwin-Weddle M., Walking the Way of Peace: Quaker Pacifism in the Seventeenth Century, Oxford: Oxford University Press, 2001.

$72016 \mathrm{~m}$. tokio tipo pacifistini nusiteikimą pasauliui priminè Holivudo ekranizuota ir „Oskaru“ apdovanota Dezmondo Doso (D. Doss) istorija. Melo Gibsono (M. Gibson) režisuoto filmo „Hacksaw Ridge“ (lietuviškas pavadinimas - „Pjūklo ketera“) pagrindinis herojus - provincialus amerikietis jaunuolis, $1944 \mathrm{~m}$. savanoriu užsirašęs ị kariuomenę, kad padètų savo šaliai (JAV) kovoje su Japonija, bet dèl nepalenkiamų religinių ịsitikinimu (adventistas) netgi karinio tribunolo akivaizdoje nesutikęs paimti ginklo ị rankas. Tapęs beginkliu sanitaru pačiame mūšių dèl Okinavos pragare (1945 m.), jis, nepaisydamas kulkų ir skeveldrų, suteikè pirmąją pagalbą daugybei sužeistų kuopos draugų, vilko juos iš kautynių lauko. D. Doso moralinè laikysena ir žygdarbis plačiai pagarsėjo, buvo ịvertinti aukščiausiais valstybiniais apdovanojimais. Be to, reikia pažymėti, kad laikotarpiu tarp dviejų pasaulinių karų didžiausiose totalitarinèse valstybėse - Sovietų Sąungoje ir nacių Vokietijoje - net ir religinès „prigimties“ pacifistinių pažiūrų besilaikantys žmonès ir jų bendrijos patirdavo žiaurų persekiojimą. Jie netoleruoti ir pokarinèje Sovietų Sąjungoje. Persekiojimas atgimė ir nūdienos Rusijoje. Antai 2017 m. balandžio pabaigoje imtasi teisinių priemonių Jehovos liudytojų, garsėjančių savo pacifistinèmis nuostatomis, legaliai veiklai nutraukti. Žr.: www. delfi.lt/news/daily/world/Rusijos-teismas-uzdraude-jehovos-lidytojus.d?id=74421050. 
venęs juristas Hugo Grocijus (H. Grotius, 1583-1645 m.) ${ }^{8}$, bet dar toliau, plètodamas ją savo traktate „I amžinąją taiką" (vok. Zum ewigen Frieden. Ein philosophischer Entwurt, 1795 m.), pažengè vokiečių filosofas Imanuelis Kantas (1724-1804 m.) $)^{9}$. Šviesių, autoritetingų asmenybių skleidžiamos humaniškos idejos rado šalininkų ir gana sparčiai plito. Oficialios „taikos bičiulių“ draugijos Europoje pradejo kurtis XIX a. pirmoje pusèje. 1843 m. Londone įvyko Pirmasis generalinis taikos konventas (angl. First General Peace Convention): susirinko 334 dalyviai, kurių dauguma buvo britai, 26 delegatai iš JAV ir tik 6 iš kitų Europos valstybių ${ }^{10}$. Taigi pacifistų judejimo pradininkai ir aktyviausi nariai iš pradžių buvo britai, bet po kelių dešimtmečių iniciatyvą perèmė prancūzai. XIX amžiuje pacifistų draugijos išplito ne tik visame Europos žemyne ir JAV ${ }^{11}$, jų atsirado ir Japonijoje, Pietų Amerikos šalyse. Rusijos imperijoje platesnei pacifistų veiklai sąlygos buvo gana komplikuotos, tačiau juos visame pasaulyje išgarsino rašytojas Levas Tolstojus (1828-1910 m.).

Vakaruose pacifistų judejjimas apogèjų pasiekè $1889-1914 \mathrm{~m}^{12}$ Jis nebuvo visiškai vienalytis, todèl tyrejjų yra skirstomas $\mathfrak{i}$ atšakas pagal ideologines ištakas (socialistinè ir krikščioniškoji-humanistinė) arba pagal reikšmingiausias tarptautines organizacijas ${ }^{13}$. Nepaisant to, šis savotiškas pacifistų internacionalas suvaidino reikšmingą vaidmenị kuriant tarptautinès humanitarinès ir karo teisès principus (pvz., 1899 ir 1907 m. Hagos konvencijos), plètojant dar 1863 m. ịsteigto Raudonojo Kryžiaus veiklą, keliant $1901 \mathrm{~m}$. pradètos teikti Nobelio taikos premijos ${ }^{14}$ prestižą.

8 Anderski S., The Novelty of Pacifism // West European Pacifism, min. veik., p. 3.

9 Cady D. L., min. veik., p. 10.

10 Cooper S. E., Patriotic Pacifism: Waging War on War in Europe 1815-1914, Oxford: Oxford University Press, 1991, p. 22.

11 Ten pat, p. 60.

12 Ten pat, p. 219-220.

13 Būtina paminèti dvi svarbiausias tarptautines organizacijas, susikūrusias 18891891 m. Pirmoji vienijo Vakarų Europos šalių parlamentarus ir vadinosi Tarpparlamentine sąjunga (ang. Inter-Parliamentary Union). Antrosios veikla reiškèsi per 1889-1914 ir 1919-1939 m. vykusius visuotinius taikos kongresus (angl. Universal Peace Congress) ir nuolatinị $1891 \mathrm{~m}$. ịkurtą organą - Tarptautinị taikos biurą (pranc. Bureau International de la Paix), ị kurio vadovaujamą judejjimą ịsijungè apie milijoną europiečių ir amerikiečių: Cooper S. E., min. veik, p. 8.

14 Beje, pirmasis asmuo, gavęs Nobelio taikos premiją (1901 m.), buvo Raudonojo Kry- 
Didžiojo, arba Pirmojo pasaulinio, karo išvakarèse ir jam vykstant (1914-1918 m.) Vakarų Europos visuomenèse pacifistinès organizacijos buvo ganètinai stiprios: jų idejos, net ir susidurdamos su vyriausybių spaudimu bei karo cenzūra, „spinduliavo“ iš grožinès literatūros, prasiskverbdavo ị spaudą, veikè gyventojų mases ${ }^{15}$. Siaubinga karo patirtis, atskleidusi sunkiai suvokiamą žmogaus gyvybès nuvertèjimą, sukèlè pasibaisejjimą militarizmu ir paskatino dar platesnị pacifistinių nuotaikų plitimą ${ }^{16}$. Dèl to kūrèsi naujos, reformavosi anksčiau veikusios, o paskui neretai ir tarpusavyje jungèsi ịvairios nacionalinès pacifistų draugijos. Tačiau šis konsolidacijos procesas nesibaigè vieno pasaulinio branduolio susidarymu. Tarpukariu egzistavo bent keletas ryškesnių tarptautinių pacifistinių organizacijų. Gana aktyviai veikè atsinaujinęs Tarptautinis taikos biuras, o $1921 \mathrm{~m}$. Nyderlanduose buvo ịsteigtas karo priešininkų internacionalas „Paco“ (esperanto kalba pavadinimas reiškia taiką), vienijęs daugiau nei trisdešimties šalių atstovus. XX a. trečiojo dešimtmečio viduryje èmé plisti grafo Rišaro Nikolo Kudenhove-Kalergi ( $R$. N. Coudenhove-Kalergi, 1894-1972 m.) inspiruotas Paneuropos judejimas, skelbęs taikaus Senojo žemyno tautų susivienijimo idejją. Jị labai rèmè įtakingi Prancūzijos politikai ir pasaulyje garsūs mokslininkai, tarp jų - Albertas Enšteinas (A. Enstein, 1879-1955 m.), Zigmundas Froidas (S. Freud, 1856-1939 m.). Antikarines nuostatas tada taip pat propagavo gana daug žinomų rašytojų, tokių kaip Nobelio premijos laureatas britas Džordžas Bernardas Šo (G. B. Shaw, 1856-1950 m.) ${ }^{17}$ arba vokietis Tomas Manas (T. Mann, 1875-1958 m.), kiti ịvairių sričių menininkai. Ne mažiau svarbu

žiaus organizacijos įkūrèjas šveicaras Anri Diunanas (H. Dunant, 1828-1910 m.): Eretas J., Krauju aplaistomas jubiliejus // XX amžius, 194002 03, p. 3.

15 Žr. pvz.: Tyle C. M., The Great War and Women's Consciousness: Images of Militarism and Womanhood in Women's Writings 1914-1964, London: Macmillan 1990, p. 103-129; White R. S., Pacifism and English Literature: Ministrels of Peace, New York: Palgrave Macmillan, 2008. Net ilgai kurstytų karingų nuotaikų apimtoje Vokietijoje $1914 \mathrm{~m}$. vasaros pabaigoje vyko gana didelès socialdemokratų organizuotos pacifistinès demonstracijos: Verhey J., The Spirit of 1914: Militarism, Myth and Mobilization in Germany, second ed., Cambridge: Cambridge University Press, p. 2003, p. 52-57.

16 Berghahn V. R., Europe in The Era of Two World Wars: From Militarism and Genocide to Civil Society, 1900-1950, Princeton: Princeton University Press, 2006, p. 70.

17 Verta priminti, kad 1925 m. apdovanotas Nobelio premija už literatūrą B. Šo atsisake paimti pinigus, kaip pats teigè, dèl to, kad jie buvo skirti iš kapitalo, sukaupto už sprogstamųjų medžiagų patentus: White R. S., min. veik., p. 61. 
ir tai, jog tuo metu pacifizmo idejjos plètotè nustojo būti vien europiečių arba, plačiau imant, Vakarų krikščioniškosios civilizacijos atstovų prerogatyva. Svarų indèlị šioje srityje paliko Indijos nacionalinio išsivadavimo lyderis Mohandas Karamčiandas Gandi (M. K. Gandhi, 1869-1948 m.), tarp savo šalininkų gavęs Mahatmos („Didžiosios sielos“) vardą.

Taikos išsaugojimas po Didžiojo karo tapo oficialiu prioritetu ir politiniu lygmeniu. Šiuo siekiu buvo pagrịstas Tautų Sąjungos ịsteigimas ir veikla. XX a. trečiajame dešimtmetyje Europoje buvo pasirašyta nemažai tarpvalstybinių sutarčių (pirmiausia pažymėtinos 1925 m. Lokarno sutartys ir $1928 \mathrm{~m}$. Briano-Kelogo (Briand-Kellog) paktas), kuriomis šalys signatarès oficialiai pasižadejjo nebeeskaluoti ankstesnių prieštaravimų ir atsisakyti karine jèga paremtų santykių. Tačiau vèliau per dešimt metų šie issipareigojimai prarado bet koki poveiki realybei - 1939-1945 m. pasaulis degè naujo, dar baisesnio karo liepsnose. O jam pasibaigus, siaubingu griuvėsių, genocido nusikaltimų akivaizdoje vèl atsigręžta i̇ pacifistinị idealą, tiesa, ne visai nuoširdžiai, nes juo ne tik bandyta grịsti kelią i šviesią žmonijos ateitị, bet ir naudotasi kaip priemone agresyviems tikslams užmaskuoti. Taip kova už visuotinę taiką, nusiginklavimą tapo vienu iš svarbiausių destruktyvios ir ciniškos Sovietų Sąjungos propagandos leitmotyvų Šaltajame kare ${ }^{18}$. Neretai pasitelkdama angažuotus „kapitalistinio pasaulio" intelektualus, Maskva nuolat kaltino JAV ir kitas Šiaurès Atlanto sutarties organizacijos (NATO) nares imperializmu ir militariz$\mathrm{mu}$, nors pati akivaizdžiai puoselèjo globalios ekspansijos siekius. Tačiau svarbu akcentuoti, jog pacifistiniame judejjime Vakaruose būta ne tik savanaudiško angažuotumo, bet ir sąžiningo idealizmo. Ryškus autentiško viešo autoriteto pavyzdys - nesmurtinị pasipriešinimą afroamerikiečių segregacijai propagavęs pastorius Martinas Liuteris Kingas jaunesnysis (M. L. King Jr., 1929-1968 m.).

Tendencingi „Amerikos militarizmo“ demaskavimo veiksmai nesibaigè, pasibaigus Vietnamo ir net Šaltajam karui. Ši tradicija tarsi naujai atgijo po $2001 \mathrm{~m}$. rugsèjo 11-osios tragedijos, prasidejus karinèms kampanijoms Afganistane ir Irake. Tai iliustruojančių pavyzdžių rasti nesunku netgi pavarčius Vakaruose solidžių leidyklų išleistą politologinę

18 Harmel C., The Soviet Union and the Uses of Pacifism // West European Pacifism and the Strategy for Peace, ed., P. van den Dungen, New York: Palgrave Macmillan, 1985, p. 158-170. 
literatūrą ${ }^{19}$. Kitas populiarus vienpusių kaltinimų objektas - Izraelis. Jis dèl ypatingo dèmesio savo saugumui ir aktyvios gynybos politikos taip pat labai dažnai yra puolamas kairuoliškų pažiūrų demokratinio pasaulio žurnalistų, tarptautinių organizacijų aktyvistų ir net akademinės sferos atstovų $^{20}$. Tai neturètų stebinti - pacifistinès nuotaikos ne tik šiandieninès Vakarų Europos intelektualų, bet ir gyventojų yra stiprios ${ }^{21}$. Tai pirmiausia pasakytina apie Vokietiją, kurioje psichologinė Antrojo pasaulinio karo trauma skaudžiai išgyvenama visą antrąją XX amžiaus pusę ${ }^{22}$. Rytų Azijoje šiek tiek panaši buvo Japonijos situacija ${ }^{23}$.

Visa ši glausta istorinè apžvalga rodo, kokios plačios ir daugiašakès gali būti pacifizmo ir militarizmo - dviejų visiškai priešingų, bet iš esmès beveik neatskiriamų reiškinių - studijos. Anglosaksiškoje akademinejje

19 Žr. pvz.: Bacewich A.J.,The New American Militarism: How Americans Are Seduced by War, Oxford: Oxford UP, 2005; Martin G., Steuter E., Pop Culture Goes to War: Enlisting and Resisting Militarism in the War on Terror, Lanham-Plymouth: Lexhington books, 2010; Branagan M., Global Warming, Militarism and Nonviolence: The Art of Active Resistance, Basingstoke: Palgrave Macmillan, 2013.

20 Daugelis jų publikuotų tyrimų yra ganètinai tendencingi. Kita vertus, ir patys Izraelio politologai nestokoja kritiško požiūrio ị savo valstybès karinius reikalus, militarizmo tema jiems nèra tabu. Tokio subalansuoto analitinio tyrimo pavyzdžiu gali būti laikomas šis straipsnių rinkinys: Militarism and Israeli Society, ed. G. Sheffer, O. Barak, Bloomington: Indiana University Press, 2010.

21 Noro aktualizuoti pacifistinę mintị Europos Sąjungoje iliustracija galima laikyti ir Austrijos išleistas dviejų eurų nominalo monetas su Bertos fon Sutner (B. von Suttner, 1843-1914 m.) atvaizdu (žr.: www.ecb.europa.eu/euro/coins/2euro/). Ši senos Habsburgų imperijos aristokratų giminės atstovè savo visuomeninę veiklą ir literatūrinę kūrybą skyrè pacifizmo propagavimui. $1905 \mathrm{~m}$. šis jos humanistinis indèlis į žmonijos santykių tobulinimą buvo įvertintas Nobelio taikos premija. Žr.: www.nobelprize.org/nobel prizes/ peace/laureates/1905/suttner-bio/).

Tai, kad monetas papuošè ne kokios nors kitos, nepalyginamai žinomesnès pasaulinio masto asmenybès (kurių istorinė Austrija vien tarp muzikų, rašytojų ir mokslininkų turi isspūdingą plejadą), o B. fon Sutner portretas - nors ir nedidelis, bet labai iškalbingas simbolis, atspindintis plačią ir savotiškai ambicingą tendenciją.

22 Išsamiai žr.: Dalgaard-Nielsen A., Germany, Pacifism and Peace Enforcement: Manchester University Press, 2006.

23 Išsamiai žr.: Yamamoto M., Grassroots Pacifism in Post -War Japan. The Rebirth of a Nation, London - New York: Routledge Curzon, 2005; Chiba S., On Constitional Pacifism in Post-War Japan: Its Theoretical Meanings // Peace Movements and Pacifism after September 11., eds. S. Chiba, T. J. Schoenbaum, Northampton: Edward Elgar Publishing Inc., 2008, p. 128-154. 
terpeje jos yra nepaprastai išplètotos, dèl to sunku aprèpti bei pristatyti net ir žymiausius veikalus. Lietuvos socialiniai ir humanitariniai mokslai šiuo požiūriu atrodo gana kukliai, nors iš tiesų juos lyginti su vakarietiškaisiais dèl skirtingų istorinių aplinkybių poveikio ir turimų išteklių nelabai adekvatu. Nepriklausomos Lietuvos kariuomenès dvidešimtmečio tyrimų, kuriuose vienaip ar kitaip prisiliečiama prie militarizmo, visuomenès militarizacijos problemų, jau šiek tiek yra ${ }^{24}$, tačiau pacifizmo temai dèmesio iki šiol beveik nebuvo skirta. Iš dalies tokią situaciją galima suprasti: Lietuvoje XX a. 3-4 dešimtmetyje apie tai mažai ir dažnai nelabai aiškiai kalbèta, didesnès diskusijos neịsiplieksdavo. Visai kitokia reikšmè tam buvo teikiama to meto Vakarų Europoje ir už Atlanto, taip pat Sovietų Sąungoje. Vien jau dèl to verta pabandyti įdemiau pažvelgti, kiek ir kaip šios tendencijos atsispindèjo mūsų krašte, pasvarstyti, kas tai lèmè.

Straipsnio tikslas - apibendrinti pacifistinių nuostatų refleksiją Lietuvos viešojoje erdveje XX a. 3-4 dešimtmetyje. Šiam siekiui igyvendinti numatyti keturi uždaviniai: 1) išryškinti globalių antikarinių nuotaikų atspindžius viešajame gyvenime; 2) pristatyti pacifistinių idejjų reiškejjus ir jų vertinimus tuometeje Lietuvoje; 3) išanalizuoti militarizmo ir antimilitarizmo priešpriešos bruožus oficialiojoje retorikoje; 4) įvertinti ryšio tarp nuolatinès karo grèsmès ir pacifistinių idejų patrauklumo Lietuvoje galimybę.

Straipsnis orientuotas ị bendrąsias, viešojoje erdvèje ryškiausiai atsiskleidusias pozicijas pacifizmo tema, jame nesiekiama nagrinèti nedidelių, nelabai ịtakingų draugijų, siaurų intelektualų sambūrių ar paskirų asmenybių nuostatų bei veiklos ${ }^{25}$. Tai galètų tapti kitų - savarankiškų,

24 Žr. pvz.: Surgailis G., Karinès ir visuomeninès organizacijos Lietuvoje 1918-1940 metais // Karo archyvas, 1997, t. XIV, p. 48-99; Surgailis G., Lietuvos kariuomene 1918-1998 m., Vilnius: LR krašto apsaugos ministerija, 1998; Vaičenonis J., Lietuvos kariuomene valstybés politinio gyvenimo verpetuose (1927-1940), Vilnius: Versus aureus, 2004; Jokubauskas V., „Mažujų kariuomeniu“ " galia ir paramilitarizmas. Tarpukario Lietuvos atvejis, Klaipeda: Klaipedos universiteto leidykla, 2014.

25 Suskaičiuoti tarpukario Lietuvoje oficialiai ar pusiau oficialiai veikusias visuomenines, kultūrines organizacijas, religines-filosofines grupes, kurios ne tik vienaip ar kitaip reflektavo, bet ir palaikè pacifistines idejjas, gana sunku dèl diagnozei būtinų „simptomų“ (kriterijų) sąlygiškumo ir tokio pobūdžio platesnių tyrimų trūkumo. Pacifistinès pakraipos paramasoniško internacionalo atstovus savo monografijoje trumpai yra pristačiusi Laima Kastanauskaitė. Žr.: Kastanauskaitė L., Lietuvos inteligentija masonų ir paramasoniškose organizacijose (1918-1940), Vilnius: Vaga, 2008, p. 30-92, 96-104. 
siauresnių - tyrimų objektu. Kol kas prasmingiausia, atrodo, būtų pačiai problematikai suteikti tam tikrus kontūrus, kurie vèliau palengvintų gilesnę konkrečių aspektų analizę tiems, kas tuo susidomès. Suprantama, mūsų pateiktas požiūris dèl subjektyvių paklydimų galimybès tikrai nepretenduoja tapti nepajudinamu, nebekoreguojamu kitų analogiškos tematikos ir problematikos darbų pagrindu.

Straipsnio koncepcija ipareigoja šiek tiek stabtelèti ir pakomentuoti tyrimo ašimi tapusius terminus. Iš karto tenka konstatuoti, jog jie tiek nagrinėjamo laikotarpio amžininkų, tiek šiuolaikinių politologų apibūdinami kaip daugiaprasmiai: gali būti aiškinami labai paprastai - vos vienu sakiniu arba sudètingai, išskiriant ịvairias išlygas ir niuansus. Tačiau nuo galimų komplikacijų gelbsti tai, jog daugumoje tyrime naudotų šaltinių (periodikoje ir kituose spaudiniuose) i platesnius teorinius išvedžiojimus nesileidžiama. Analizuotuose tekstuose dažniausia dominuoja du reikšminiai žodžiai: „pacifistai“ (arba „taikos šalininkai“) ir „karo priešininkai“ („antimilitaristai“) ${ }^{26}$, kurie labai dažnai vartojami kaip sinonimai, nors tai - ne visai tikslu. „Pacifizmas“ - platesnis terminas, žymintis suabsoliutintą taikos idejją, kai smerkiami ne tik karai, bet ir fizinè prievarta tarp žmonių ${ }^{27}$. Antikarinès nuostatos - tai sudètinè pacifizmo dalis, siauresnis jo aspektas. Prieinamiausiuose lietuviškuose tarptautinių žodžių žodynuose pacifizmo terminas aiškinamas supaprastintai, akcentuojant pirmiausia antikarinị jo turinị $\mathfrak{i}^{28}$. Tik specializuotoje akademinèje literatūroje išryškinami iš giluminių apmąstymų kylantys įvairūs papildomi kontekstiniai, semantiniai niuansai ${ }^{29}$. Analizuojant pacifizmo sampratas ne-

\footnotetext{
26 Dabartinis ir anuometinis antimilitarizmo termino aiškinimas iš esmès nesiskiria: „Plačiąja prasme [tai] - kariuomenès, karo tarnybos ir apskritai karo neigimas“. Žr.: Antimilitarizmas // Lietuviškoji enciklopedija, t. 1, Kaunas: Spaudos fondas, 1933, p. 204.

27 White R.S., min. veik., p. 6.

28 Žr. pvz.: www.zodynas.lt/terminu-zodynas/p/pacifistas; www.lietuviuzodynas.lt/terminai/pacifizmas.

29 Pavyzdžiui, Duglas P. Lekis (D. P. Lackey) išskyrè keturis pacifizmo tipus: 1) Universalusis krikščioniškasis pacifizmas, skelbiantis, kad žudyti yra nuodèmė. 2) Universalusis Gandžio pacifizmas, atmetantis prievartos naudojimą, siekiant politinių tikslų. 3) Dalinis, arba ribotas, šv. Augustino pacifizmas, smerkiantis smurtą tarp individų, bet pateisinantis valstybès prievartos monopolị, teisę kariauti gynybinį karą. 4) Antikarinis pacifizmas, kuris yra ribotas dèl to, kad smerkia karus, bet pateisina asmens teisę ị savigyną. Žr.: Lackey D.P., The Ethics of War and Peace, New York: Prentice Hall, 1989, p. 6-24. Dar ivai-
} 
išvengiamai tenka susidurti su jam priešingu terminu - „militarizmas“30, todèl ji prasminga bent trumpai pakomentuoti. Militarizmo aiškinime taip pat yra išryškejjusios dvi esminès plotmès. Jas ịtvirtino šio reiškinio tyrimų pradininku laikomas vokiečių kilmès, bet anglosaksiškoje akademinëje terpèje išgarsėjęs istorikas Alfredas Vagtsas (A. Vagts, 1892-1986 m.). Savo dar 1937 m. pirmąkart išleistame ir klasika virtusiame veikale "Militarizmo istorija“ jis konstatavo egzistuojant dvi militarizmo formas - kariškių (angl. militarism of the military) ir civilių (angl. civilian militarism) ${ }^{31}$. Pirmoji forma žymi kariškių dominavimą valstybès valdyme, jos resursų pajungimą ginklavimuisi, agresyviai užsienio politi$\mathrm{kai}^{32}$. Antroji - valstybès piliečių militarizaciją - sukarinimą ne tik tiesiogine (karinio parengimo), bet ir kultūrine prasme. Pastaruoju atveju šalyje plačiai diegiamos ir propaguojamos kariškos vertybès (narsa, kovingumas, disciplina, subordinacija ir t. t.) ir kariška stilistika (uniformos, ceremonijos). Tai nebūtinai susiję su pasirengimu kokiam nors konkrečiam

resnis pacifizmo tipų, kilusių iš skirtingų religinių arba filosofinių nuostatų, spektras pristatytas Peterio van den Dungeno straipsnyje. Žr.: Van den Dungen P., Pacifism:Sources of Inspiration and Motivation // West European Pacifism, min. veik., p. 29-30. Tarpukario Lietuvoje bandymų moksliškai tipologizuoti ir analizuoti pacifizmo sampratas būta nedaug. Vienas iš reikšmingesnių šiuo požiūriu, regis, būtų teisininko, dėsčiusio Vytauto Didžiojo universitete, Martyno Kavolio indèlis. Savo publikacijoje „Socialinè taikos ir karo reikšme““ jis išskyre keturias pacifizmo paradigmas: 1) „Asketiškoji taikos pažiūra“ krikščioniška artimo meile grịstas pacifizmas. 2) „Imperialistinė arba absoliutinè taikos pažiūra" - užkariautojų pasiteisinimas, jog jie savo valdas plečia, siekdami kuo platesnio taikos ir „teisingos“ tvarkos ịtvirtinimo. 3) „Politinè taikos pažiūra“ - nuostata, kad taiką tarp valstybių gali užtikrinti jų konstruktyvus bendradarbiavimas tarptautinėse institucijose ir savotiška integracija. 4) „Teisiškoji taikos pažiūra“ - nuostata, grịsta tikejjimu teisès principų viršenybe, jų galia sureguliuoti santykius tarp valstybių. Šiuo atveju priimtinu laikomas tik karas teisei apginti. Žr.: Kavolis M., Socialinè taikos ir karo reikšmė // Mūsu žinynas, 1937, Nr. 4, p. 404.

30 Literatūroje anglų kalba, ypač filosofinio pobūdžio, kartais yra vartojamas specifinis terminas „Warism“, žymintis savotišką militarizmo atitikmenį arba - tiksliau - kraštutinę jo išraišką. Šj terminą išversti i lietuvių kalbą sunku. Jis reiškia ne tik karo pateisinimą, bet ir savotišką jo šlovinimą, paremtą ịsitikinimu, kad tai yra progreso ir visokeriopo atsinaujinimo šaltinis. Žr. pvz.: Cady D. L., From Warism to Pacifism: A Moral Continum, second ed.: Philadelphia: Temple University Press, 2010.

31 Plačiau žr.: Vagts A., A History of Militarism: Civilian and Military, second. ed. New York: Meridian books, 1959, p. 13-17.

32 Žr. pvz.: www.zodynas.lt/terminu-zodynas/m/militarizmas; www.lietuviuzodynas.lt/ terminai/militarizmas. 
numatomam kariniam konfliktui - svarbiausia čia atitinkama atmosfera, „paradinis“ ritmas, forma, fonas. Panašiai šiuos du reiškinius atskyre ir vẻlesni jų tyrejjai, nors esama ir tam tikrų papildymų bei korekcijų ${ }^{33}$.

Straipsnyje, analizuojant požiūrị i pacifizmą ir (neišvengiamai) i militarizmą tarpukario Lietuvoje (XX a. 3-4 deš.), pirmiausia vadovaujamasi istorizmo principu, t. y. siekiama atskleisti šių reiškinių sampratas tiriamuoju laikotarpiu, susilaikant nuo šiandien gana madingos tendencijos praeities reiškinius dirbtinai „pritempti“ prie šiuolaikinių „universalių“ teorinių schemų.

\section{GLOBALIŲ ANTIKARINIŲ NUOTAIKŲ ATŠVAITAI LIETUVOJE XX A. PIRMOJE PUSĖJE}

XX a. antrojo ir trečiojo dešimtmečių sandūroje, kai Lietuva po ilgai trukusios svetimųjų priespaudos kaip valstybė pasauliui atgimè nedidelès, nepriklausomos, $\mathfrak{i}$ modernèjimą orientuotos respublikos pavidalu, institucionalizuotas pacifizmas (oficialios nacionalinès draugijos, ilgainiui išplètojusios tarptautinius ryšius) Europoje ir JAV egzistavo beveik šimtą metu. Tada tai jau nebuvo vien visuomeniniai judejjimai - jų idejjas, nors neretai tik deklaratyviai, palaikè ir dauguma pažangiausių demokratinių šalių vyriausybių. Vaizdžiai tariant, pacifistinė mintis sudygo kaip sèkla, virto augalu, žydèjo ir mezgè vaisius. Po Didžiojo karo prasidejjo naujas vilčių ir nusivylimų etapas, susijęs su 1919 m. Paryžiaus taikos konferencija, Tautų Sąjunga ir įvairiomis tarptautinemis taikdariškomis iniciatyvomis. Be to, būta ịvykių ir ne didžiosios politikos sferoje, kurie

\footnotetext{
33 Antai Džonas R. Džilis (J. R. Gillis) pirmenybę teikè siauresniam militarizmo apibrèžimui, esminiu jo kriterijumi laikydamas kariškių dominavimą valstybès valdymo struktūroje. Visuomenès karingumo ugdymą, jos karinio parengimo procesą mokslininkas vadino militarizacija. Gillis J. R., Introduction // The Militarization of the Western World, ed. J. R. Gillis, London: Rutgers University Press, 1989, p. 1. A. Vagtso apibrěžtasis „kariškių militarizmas“ kai kurių kitų autorių yra vadinamas „politiniu militarizmu“, o „civilių militarizmas“ - visuomeniniu arba socialiniu militarizmu (angl. social militarism). Žr.: Berghahn V. R., Europe in the Era of Two World Wars: From Militarism and Genocide to Civil Society, 1900-1950, Princeton: Princeton University Press, 2006, p. 73; Johnson M., Militarism and The British Left, 1902-1914, Basingstoke: Palgrave Macmillan, 2013, p. 7-10.
} 
vienaip ar kitaip suaktualino pacifistines ir antikarines nuostatas. Parodyti, kiek ir kaip tai atsispindejo Lietuvos viešojoje erdvejje, ir bus bandoma šiame skyriuje.

Prieš sutelkiant tiriamąji žvilgsni i XX a. 3-4 dešimtmečių lietuviškosios spaudos puslapius, tenka padaryti nedidelị apibendrinamąji ekskursą i moderniojo Lietuvos valstybingumo išvakares - tautinio sąjūdžio atomazgos laikotarpi. Jis iš esmès sutapo su taikos idejų sklaidos apogejjumi prieškariniame Vakarų pasaulyje. Pacifistų internacionalo tema, neperžengianti carinès cenzūros leidžiamų ribų, yra pastebima pirmuosiuose legaliuose lietuviškuose laikraščiuose, pirmiausia kairiosios, tada save vadinusios „pirmeiviškąja“, pakraipos. Tereikia pavartyti „Naująją gadynę“ ar „Lietuvos žinias“. Tai - dèsningas reiškinys: Europoje pacifistines nuostatas tada (o ir vèliau) stipriausiai reiškè ịvairaus plauko socialistai ir anarchistai $^{34}$. Kita vertus, prielankumo taikos idejai netrūko ir katalikiškoje spaudoje, kuri to meto Lietuvoje leista didžiausiais įmanomais tiražais (pavyzdžiui, savaitraštis „Šaltinis“ - 15 tūkst. egzempliorių) ir pasiekdavo plačias gyventojų mases ${ }^{35}$. Apskritai kone visų lietuvių tautinio sąjūdžio politinių ir pasaulèžiūrinių srovių publicistų tekstuose ginkluotos kovos metodai laikomi nepriimtinais, kariškos vertybės, karo tarnyba nėra aukštinama. Tai - liūdnai pasibaigusių 1831 ir 1863 m. bajoriškųų sukilimų, beprasmiškai pražūtingos rekrutų prievolès ir reformuoto jos pakaitalo patirčių atgarsis. Ir to meto grožinèje literatūroje „kareiviavimo“ motyvas beveik visada apipintas tragiškos lemties gija. 1904 m. Rusijos-Japonijos karas tik dar labiau sustiprino tokias iš esmès pacifistines nuotaikas. To meto lietuvių visuomeneje imperinis patriotizmas nebuvo ryškus, nepasiduota ir smurtinems 1905-ųjų revoliucijos aistroms. Lietuviškose gubernijose ji praejjo nepalyginamai taikiau nei latvių ar lenkų žemèse ${ }^{36} .1914 \mathrm{~m}$. vasarą didžiuosiuose Rusijos miestuose suputojusi vokiečių sutriuškinimo „užmètant juos kepurèmis“ isterijos banga lietuviškąją inteligentiją atvirai glumino. Tolesnè karo eiga, kaizerinès okupacijos brutalumas tik stiprino rezignaciją, priešiškumą prievartai. Ryškiau išreikštos ginkluotos kovos ar

\footnotetext{
34 Johnson M., min. veik., p. 1.
}

35 Urbonas V., Lietuvių periodinè spauda: raidos istorija ir dabartis // Gimtasis kraštas: praeities ir dabarties kultūros metraštis, 2012, t. 5, p. 51.

36 Aleksandravičius E., Kulakauskas A., Carų valdžioje: XIX amžiaus Lietuva, Vilnius: Baltos lankos, 1996, p. 153-155. 
juo labiau keršto dvasios to meto lietuviškos visuomenès autoritetų dienoraščiuose ir kiek vèliau rašytuose atsiminimuose beveik nėra. Tačiau 1918-1920 m. realijos krašte privertẻ prislopinti humanistines nuostatas ir pasiduoti išlikimo ginkluotoje kovoje instinktui. Viešosios politinès retorikos tonas tapo kur kas ryžtingesnis, radikalesnis, nors nenusisukta ir nuo idealistinių vilčių - tikejjimo didžiųjų demokratijų deklaruotais visuotinès taikos siekiais. Lietuvos sąlygomis tokia pacifizmo nuotaika kaip pokarinejje Vakarų Europoje nelabai galejjo formuotis. Tačiau tam tikrų jos atspindžių, pirmiausia kultūros sferoje, būta. Juos dažniausiai inicijuodavo inteligentai ir menininkai, lankęsi ar studijavę Vokietijoje, Šveicarijoje, Prancūzijoje, skaitę tų šalių spaudą, užčiuopę tenykščių kūrẻjų, intelektualų gyvenimo pulsą ${ }^{37}$. Vis dèlto tai neturèjo didesnio poveikio nei Lietuvos visuomenès sąmonei, nei valdžios viršūnès politinėms vizijoms. Gyvenimo realybẻ neleido ilgiau puoselèti idealistinių vilčių. Taip lūkesčiai, susieti su Vakarų demokratijų deklaruotomis taikos išsaugojimo Europoje perspektyvomis, gana greitai - dar neịpusejjus XX a. trečiajam dešimtmečiui - èmé blankti, o kartais net igaudavo piktoko skepsio pavidalą $^{38}$. Tai nesunku pastebèti įdèmiau pažvelgus ị kai kurias tuometinio oficiozo pirmuosiuose puslapiuose pateiktas publikacijas. Kritišką jų toną lèmé nepalankia Lietuvai linkme besiklostanti „Vilniaus byla“. Antai po ciniškos real politik simboliu lietuvių visuomenei tapusios 1923 m. Am-

37 Kaip pavyzdị galima nurodyti kad ir ambicingą literatų avangardistų sambūrị, ị viešumą išẻjusị 1922 m. su leidiniu „Keturių vẻjų pranašas“, o 1924-1928 m. leidusị literatūrinị žurnalą „Keturi vejjai“. Šio sambūrio pagrindinis „ideologas“ Kazys Binkis 1920-1921 m. „žmonèjosi“ Berlyne. Kaip tik tada jis perskaitė savotiška sensacija tapusį vokiečių rašytojo Bernhardo Kelermano (B. Kellermann) antikarinį romaną „Lapkričio 9-oji“ (Der 9 November), kuriame dramatiškai pavaizduota, kaip kaizerio armijos štabo vadovybė pasmerkia beprasmiškai mirčiai savo karius, davusi įsakymą žūtbūt išlaikyti Keturių vèjų (pranc. Quatre vents) kalvą. Iš čia ir lietuviškojo žurnalo pavadinimas, turèjęs simbolizuoti ryžtingos, sąmoningos mažumos pasiaukojamą kovą už meno atsinaujinimą. Žr.: Kuzmickas V., Kazys Binkis: Gyvenimas ir kūryba, Kaunas: Šviesa, 1985, p. 59. Beje, pirmojo žurnalo numerio viršelyje pavadinimas pirmiausia buvo užrašytas prancūziškai, o po to dar aštuoniomis kalbomis, tarp jų - ir latviškai bei estiškai (lietuviškas užrašas stambiu, raudonu šriftu sudaro tarsi foną). Nepaisant šios pavadinimo kilmès istorijos, svarbu konstatuoti, kad antikarinè ar pacifistinė retorika visuose „Keturių vejjų“ numeriuose yra neryški, „užčiuopiama“ daugiausia tik poteksteje.

38 Žr. pvz.: Dilys A., Gresiantis žmonijai pavojus, Nusiginklavimo konferencija // Lietuva, 192408 09, p. 2. 
basadorių konferencijos buvęs užsienio reikalų ministras Juozas Purickis platokame straipsnyje smarkokai išpliekè esą „veidmainiškai“ taikos ir demokratijos idejjas skleidusias Prancūziją, D. Britaniją ir JAV. Jis skaitytojams aiškino taip: „Didžiausią atsakomybę neša pasaulio šeimininkai Santarvès didžiūnai. Jie mokejjo karo metu leisti gražius obalsius, kad pritrauktų daugiau sąungininkų ir moraliai susilpnintų priešą. Jie mokejjo tą priešą [Vokietiją - M. K.], kurị jie skelbė vieninteliu militarizmo kaltininku, nuveikti, visiškai nuginkluoti ir sunaikinti materialiai. Deja, jie nemokèjo arba, teisingiau pasakius, nenorejo sutvarkyti pasaulio taip, kad valstybių ir tautų tarpusavio santykiai būtų varomi ne brutalia pajejga, bet teise ir teisingumo dėsniais. " ${ }^{39}$ Taip pat smarkiai kliuvo ir svarbiausiai pokarinę tvarką ir taiką apsaugoti turèjusiai tarptautinei institucijai. Ją J. Purickis įvertino net nebandydamas surasti bent kiek diplomatiškesnių epitetų: „Kad nepasirodytų pasaulio akyse visiškais apgavikais, jie [Santarvès nariai - M. K.] ịkūrè Tautų Sąjungą, prirašè jos statute labai gražių obalsių [šūkių - M. K.]. Bet ta Sąjunga serga ir, matyti, sirgs ir toliau rachitizmu visą savo amžių. Ji ši tą daro labdarybès ir socialinejje dirvoje, bet politikoje, savo svarbiausiame uždavinyje - ji rachitikas, neūžauga, kuris moka žaisti, bet nieko rimto nepadaro. “40 Pikta šio įžvalgaus žurnalisto prognozè netolimoje ateityje iš esmès išsipildè. Po daugiau nei dešimtmečio oficiozinè Lietuvos spauda atvirai pripažino, jog „pacifizmas šiandien pergyvena sunkią krizę ir vargu ar jis beprisikels nuo tų skaudžių smūgių, kurių jam teko patirti paskutiniuoju laiku. Pacifizmas buvo identifikuojamas su Tautų Sąjungos dvasia, bet kas šiandien bepaliko iš Ženevos įstaigos - visi matome. Tautų Sąjungos kūrèjų viltis - spręsti tarptautinius kivirčus taikiu būdu - nepasiteisino. Vèl grịžtame prie senų pajègos metodų “41.

Vis dèlto toks emocingas kaip J. Purickio požiūris Lietuvos viešojoje erdvèje ne tik trečiajame dešimtmetyje, bet ir vèliau buvo daugiau išimtis ${ }^{42}$,

\footnotetext{
39 Vygandas [J. Purickis] Militarizmas prieš Didijji karą ir po karo // Lietuva, 192310 13, p. 1.

40 Ten pat.

41 Pacifizmo krizè // Lietuvos aidas, 193604 23, p. 4.

42 Pavyzdžiui, gana aštriai pacifizmą viename straipsnyje $1925 \mathrm{~m}$. demaskavo Antanas Graurogkas: „[Pacifizmas] geras ir naudingas tenai, tose šalyse, kur manoma, kad krašto gerovė reikalauja pavergimo ir ginklu pajungimo kitų mažesnių tautų; tenai pacifizmas yra geras vaistas nuo sunkios ligos, kuri jau ne vieną didelę tautą yra pražudžiusi. Bet
} 
o ne norma. Dažniausiai spaudoje apie didžiųjų Europos valstybių taikos palaikymo iniciatyvas stengtasi atsiliepti su pagarbiu pritarimu, palaikymu, nors iš potekstės bent kiek praprusęs skaitytojas galëjo nesunkiai suprasti, jog tai laikoma formaliu diplomatinès rutinos dalyku - siekiamybe, kuri vargu ar artimiausioje ateityje bent iš dalies taps realybe ${ }^{43}$. Manyta, kad pasaulineje arenoje simboliškai ginti „taikos reikalą“ geriausia patikèti moterims - kaip motinoms, duodančioms ir puoselejančioms gyvybę. Antai $1932 \mathrm{~m}$. buvo atsiliepta ị Tarptautinès vaikams globoti sąjungos Ženevoje (pranc. Union internationale de secure aux enfants Genêve) kvietimą žymiausiems savo šalyse rašytojams periodineje spaudoje paskelbti straipsnių taikos tema. Lietuvos motinoms ir vaikams globoti organizacijų sąjunga šią garbę suteike Sofijai Čiurlionienei ${ }^{44}$. Panašus bendradarbiavi-

šaukti prie taikingumo ir naikinti karingumą ten, kur priešas tyko prie tèvynès vartų, reiškia tą patị, ką raginti prie kapituliacijos ir būti priešams talkininku. Kas tai yra, ar savižudybė... ar dar blogiau?" < ..> Imperialistinèse šalyse pacifizmo propaganda yra reikalinga sudaryti pusiausvyrai ir apsaugoti visuomenei nuo avantiūrų, iššaukiamų nesuvaldomo karingumo ir gobšumo. Lietuvos liaudis, papratusi visiems rankas bučiuoti, ta liga neserga, priešingai, jai ir karingumas, ir kitos karinès ypatybès, kol ji veda apsigynimo kovą, yra būtinos.“: Graurogkas A., Pacifizmas ir mes // Trimitas, 1925, Nr. 12, p. 354.

43 Ṣ̌ savotišką „cinizmą“" viename savo straipsnių įtikinamai pagrindè būsimasis kariuomenès vadas plk. ltn. Stasys Raštikis. Jis pažymėjo, jog per 3421 rašytinès žmonijos metus buvo 3135 karo metai, iki 1860 m. valstybès pasirašè apie 8000 taikos sutarčių, kurios trukdavo ne ilgiau kaip dvejus metus. Tad, anot Raštikio, „taip buvo praeityje, taip bus ir toliau, nes kol visi žmonès nevirs taikos ir meilès angelais, tol karai, kaip visų piktybių padariniai, neišnyks iš žmonijos gyvenimo, tai yra vienas visuomenei atmintinas dalykas“. Todèl „su ta mintimi turime apsiprasti ir pacifistų gražioms kalboms pritardami, didelių vilčių jų pastangų sèkmingumui dèti neturètume“.: a., Lietuviai, galvokime vyriškai - sako plk. ltn. Raštikis, nagrinèdamas kariuomenės ir visuomenės santykių klausimą // Lietuvos aidas, 193311 16, p. 6. Panašias mintis savo straipsnyje išdèstè ir plk. Juozas Lanskoronskis. Žr.: Lanskoronskis J., Tautos Nepriklausomybė ir kariuomenė //Lietuvos aidas, 193302 15, p. 5.

44 Pažymètina, jog S. Čiurlionienè nebuvo nuosekli pacifistė - Nepriklausomybès kovų laikotarpiu rengè ir skleidẻ karišką propagandą Lietuvos kariams ir visuomenei. Nepaisant to, prireikus ji sėkmingai susitvarkè ir su „taikos pasiuntinès“ misija. Užsakytame S. Čiurlionienès straipsnyje sudètos visos tokiu atveju reikalingos frazès, o jo turini geriausiai apibendrina ši citata: „Kai dabar pesimistai nustoja pusiausvyros ir desperatiškai skelbia Taikos idejją pralaimejjus, mums, mažos šalies piliečiams, kurie tik savo kuriamąja jèga esame gyvi, reikia juoba įsitempus kultūros darbą savo krašte dirbti ir kartu priartèti prie viso pasaulio geros valios žmonių, kurie skelbia moralinį nusiginklavimą. Tam žmonijoje sustiprèjus visi kiti nusiginklavimai lengvai bus įvykinti.“ žr.: Čiurlionienè S., Karo 
mas vyko ir vèliau. $1936 \mathrm{~m}$. Lietuvos moterų taryba nusiuntè delegates i kongresą Jugoslavijos mieste Dubrovnike, prisijungdama prie tarptautinès akcijos trisdešimt dienų (nuo gruodžio 15-osios iki sausio 15-osios) paskirti pacifizmo propagandai - èmèsi platinti specialius pašto ženklus su užrašu "Pax“ (lot. taika) bei atitinkamo pobūdžio literatūrą ${ }^{45}$. Tokia parodomoji veikla - „valdiško“, konjunktūrinio pacifizmo išraiška. Be to, reikia pažymèti, jog tos pačios Lietuvos moterų tarybos narès kartu dirbo ir „militarizmo“ labui, nes aktyviai rèmé Lietuvos kariuomenę ${ }^{46}$. Siekiant sušvelninti ši paradoksą, taikos ženkliukų platinimo akciją viešinančiame straipsnyje esminę mintị stengtasi rutulioti taip, kad idealistinès deklaracijos nesikirstų su šalies gynybiniais interesais. Šios pastangos „pagimde“ „doktriną“, kuri skelbė: „Ir šalia visuotinio tiek vyrų, tiek moterų karinio pasiruošimo, kurio iš mūsų reikalauja tèvynès laisvès saugojimo pareiga, mes garsiai galime tarti pasauliui - mes karo nenorime, mes trokštame taikos ir teisètumo. Mes stojame ị pacifistų eiles ir jų idèjas nešiojame, remiame kiekvieną pastangą ir darbą, siekiantị pasaulio taikos." ${ }^{47}$

Kituose panašiuose straipsniuose buvo raginama visas viltis dèl taikos ateityje sudèti ị vaikus - jiems skiepyti draugiškumą ir pagarbą svetimoms tautoms, pertvarkant švietimo sistemą sekti neutralitetą pasirinkusių Šiaurès šalių, o ne militaristinių diktatūrų pavyzdžiuu ${ }^{48}$.

Apskritai reikia pažymèti, kad Lietuvos spaudos puslapiuose, nors ir nereguliariai, pasirodydavo bendro pobūdžio informacijos, pristatančios tiek pacifistinio judejjimo raidą Europoje $e^{49}$, tiek žymiausius antikarinių,

pavojus jaunajai kartai // Lietuvos aidas, 193203 19, p. 7.

45 J. Žv., Pasikalbejjimas su ponia V. Lozoraitiene. Kongresas Dubrovnike. Moterų policija. Kino filmos vaikams. Apie auklejimą // XX amžius, 193612 07, p. 5; Visuomenès veikimas // Naujoji vaidilute, 1936, Nr. 12, p. 507.

46 Beleckienė O., 1936 metai Lietuvos moterų gyvenime // Naujoji vaidilutè, 1937, Nr. 1, p. 1-2.

47 F. P., Pasiruoškime gintis, bet trokštame taikaus kūrybos darbo! Dèkimès ị taikos stiprinimo talką! // Rytinis Lietuvos aidas, 193611 03, p. 2.

48 Biržiškienė B., Jaunimas ir vaikai taikos pasiuntiniai // XX amžius, 193612 22, p. 2.

49 Žr. pvz.: V. G. [V. Gustainis], Tarptautinis taikos kongresas // Lietuva, 192409 03, p. 2; Telegramos. İdomi pacifistų brošiūra E [elta], Paryžius, 30.IX // Lietuva, 192410 01, p. 7; Martel R., Pacifizmas dirba // Lietuvos aidas, 193007 14, p. 3; Martel R., Pacifistinis judèjimas Prancūzijoj. Victoro Margueritte: Non! // Lietuvos aidas, 193108 08, p. 7; Martel R., Pacifistinis judèjimas Prancūzijoj. Ernesto Judet'o „Saugumo politika// Lietuvos 
taikaus tautų sugyvenimo idejjų propaguotojus, tokius kaip L. Tolstojus, A. Nobelis, F. Nansenas (F. Nansen, 1861-1930m.), M. Gandis ir kt. Apie šias asmenybes dažniausiai rašyta pagarbiai, kaip apie iškilius kūrẻjus, moralinius autoritetus, sykiu apgailestaujant, jog jų subrandintoms geresnio pasaulio vizijoms tokie abejingi pasaulio galingieji. Skaitantys vokiečių, prancūzų kalbomis Lietuvos inteligentai turèjo galimybę susipažinti su Vakarų Europoje pagarsejjusiais antikarinio pobūdžio Adriano Gustavo Anri Barbiuso (A. G. H. Barbusse, 1873-1935 m.), Ernsto Jungerio (E. Jünger, 1895-1998 m.), Ericho Marijos Remarko (E. M. Remarque, 1898-1970 m.) ir kitų rašytojų romanais. E. M. Remarko knygos buvo išleistos ir lietuviškai, o apie kitų autorių kūrinius Lietuvos skaitytojai šiek tiek galèjo sužinoti iš kultūrinèje spaudoje pasirodžiusių išverstų ištraukų arba literatūrinių naujienų apžvalgų $u^{50}$.

Nuo XX a. ketvirtojo dešimtmečio pradžios, nuolat didèjant ịtampai tarp Lietuvos ir nacionalsocializmo keliu pasukusios Vokietijos, lietuviška žiniasklaida ị kiekvieną tarptautinèje arenoje pasigirdusị ịtakingesnio taikos šalininko balsą reaguodavo gana entuziastingai, pabrèždama Lietuvos ištikimybę teisingumo ir humanizmo principams. Sykiu tuo tarsi norèta atkreipti menamų užsienio stebėtojų dèmesị ị Lietuvos saugumo problemas $^{51}$ ir suteikti šiokią tokią viltị savajai nerimo apimtai visuomenei. $1935 \mathrm{~m}$. ginkluotas konfliktas su galinga Vokietija atrodè realus, o bent kiek apčiuopiamesnès tarptautinès paramos, nors ir desperatiškai

aidas, 193108 12, p. 7; Aidai iš užsienio. Visuomeninis gyvenimas. Nusiginklavimas // Naujoji Romuva, 1932, Nr. 3, p. 70; J. Val., B. S., Laiškai iš užsienių. Paryžius. Ar visada naudingas pacifizmas? Prancūzų pokarinis pacifizmas // Lietuvos žinios, 193311 11, p. 3; Coudenhove-Kalergi R. N., Dvidešimties metų karas. Didžiojo karo pradžios 20-ies metų sukaktuvių proga // Lietuvos aidas, 193407 30, p. 2; Pacifisto kalba atvira, nuoširdi ir įtikinama // Lietuvos žinios, 193701 27, p. 1, 6; P. K-nas, Seni kariai apie taiką. Tarptautinis kombatantų kongresas. Vokiečiai, italai ir anglai nedalyvavo. Karinga nuotaika taikos tribūnoje // XX amžius, 193807 01, p. 2; Anglijos pacifistai iš įsitikinimo. Karo tarnyba ir medis. „Ar jūs gintumètès nuo žudiko“// XX amžius, 193908 19, p. 10.

50 Išsamiau žr.: Jokubauskas V., Didžiojo karo atminimas: Diskursas ir atminimo praktika tarpukario Lietuvoje // Lituanistica, 2016, t. 62, Nr. 4, p. 237-38.

$51 \mathrm{XX}$ a. ketvirtajame dešimtmetyje pasaulinè opinija pacifistini, ištikimybe Versalio sistemos principams grịstą požiūrị ị tarpvalstybinius santykius vis dar laikè aukštesnès politinès moralès išraiška, tačiau neoficialiai toks požiūris jau nepajègè atsverti real politik motyvacijos. Kasparavičius A., Lietuva 1938-1939 m.: Neutraliteto iliuzijos, Vilnius: Baltos lankos, 2010, p. 38. 
ieškojusi, Lietuva iš esmès nesulaukè. Tiesa, toks pabrěžtinai taikingas tonas lietuviškoje žiniasklaidoje atsirado ne iš karto. 1930-1935 m. pretenzijos Vokietijai dèl nelojalumo kurstymo reikštos gana atvirai ir drąsiai, mat tikètasi, jog Vakarų demokratijos neleis vèl išvešèti vokiškajam militarizmui. Progų konstatuoti šią grèsmę tikrai netrūko: jų ėmė rastis kur kas anksčiau, nei buvo žengti pirmieji didesni Adolfo Hitlerio žingsniai laužant ginklavimosi apribojimus ir pačią Versalio sistemą. Revanšizmo stiprẻjimą vokiečių masèse išraiškingai bylojo agresyvi jų reakcija ne tik i tivairias politinio, bet ir kultūrinio gyvenimo aktualijas. Vienas iš itin simbolinių tokio pobūdžio įvykių, sulaukusių atgarsio ir Lietuvoje, buvo 1929 m. Berlyne pademonstruota jau iki tol plačiai pagarsėjusio Vokietijos rašytojo E. M. Remarko romano „Vakarų fronte nieko naujo“ (vok. Im Western nichts Neues) ${ }^{52}$ amerikietiškoji ekranizacija (angl. All Quiet in the Western Front). Radikalejanti ir vis labiau revizionistinèms nuotaikoms pasiduodanti vokiečių visuomenè šį kūrinị sutiko nevienareikšmiškai, o pati filmo premjera buvo sužlugdyta chuliganiškų veiksmų. Toms kelias dienas ìvairiuose Berlyno kino teatruose vykusioms nacionalsocialistų akcijoms vadovavo Reichstago narys Jozefas Gebelsas (J. Goebbels) - būsimasis Trečiojo Reicho propagandos ministras. Prieš pat prasidedant seansams, piktavaliai salèse tarp žiūrovų paleisdavo tai baltų pelių, tai gyvačių, paskui pradėdavo triukšmauti, išprovokuodavo muštynes su socialdemokratų šalininkais ${ }^{53}$. Dèl šių neramumų teismas nedelsdamas uždraude filmo demonstravimą. Vis dèlto ažiotažo paveikti vokiečiai masiškai plūdo ị kaimyninių šalių - Prancūzijos, Belgijos ir Olandijos - pasienio miestelius, kur turejo galimybę pamatyti tą tiek pasipiktinimo jų tèvynèje sukèlusị kino filmą ${ }^{54}$.

Po poros metų šis kontroversiškai išgarsèjęs filmas pasiekẻ Lietuvos ekranus. Suprantama, pirmiausia jis demonstruotas laikinojoje sostinèje - Kaune, viename iš geriausių ir moderniausių kino teatrų „Forum“ (dabar šis pastatas Laisvès al. pažymėtas 46 numeriu). Pasirūpinta ir

\footnotetext{
52 Martel R., „Vakaruose nieko nauja“. Knyga apie karą // Lietuvos aidas, 192907 15, p. 4.

53 A. G. [A. Gricius], Baltosios pelès, gyvatès ir peštynès Berlyno kinuose. Nacionalsocialistų kova su „Vakarų fronte nieko naujo“ filmu (Mūsų Berlyno korespondento) // Lietuvos aidas, 193012 18, p. 4.

54 A., Vokiečiams brangiai kaštavo „Vakarų fronte nieko naujo“ // Lietuvos aidas, 193103 24, p. 4.
} 
intriguojančia „ivvykio“ reklama spaudoje. Didžiausio tiražo šalies dienraščio antraštès skelbè: „Pasaulinis triumfas! Pasinaudokite nedaug kam pasitaikančia proga! Šio paveikslo mūsų publika labai laukia. Numatyti 4 seansai. “" Iš tiesų, sensacija sutraukè daugybę žiūrovų. „Lietuvos aido“ reporteris neperdèdamas konstatavo: „Tokios spūsties, tokio žmonių susigrūdimo nei viename Kauno teatre dar nematyta. Žmonių eilèms tvarkyti tiek prie kasų (šeštadienị jų prireikè net dviejų), tiek kino fojė prireikẻ geroko būrio policininkų. Dauguma žiūrovų šeštadienį bilietų negavo. Apie kino [teatrą - M. K.] „Forum“ didžiausias susigrūdimas buvo ir sekmadienį. " ${ }^{66}$ Taip pat pažymèta, jog tai ne pirmas Didžiojo karo kruvinąją dramą vaizduojantis filmas, kurị išvydo kauniečiai (anksčiau jie turëjo progų pamatyti „Vakarų frontą“, „Verdeną“, „Didijji paradą“), bet jis vienintelis sukèlè tokị ažiotažą. Kitame atsiliepime, netrukus išspausdintame tame pačiame dienraštyje, buvo palankiai įvertintas ir filmo turinys, ypatingai pažymint, kad nacionalsocialistų protestai dèl jo neva Vokietiją ižeidžiančio turinio, yra nepagrịsti ${ }^{57}$. Apskritai tuometẻ Lietuvos publika, pasipiktinusi vokiečių intrigomis Klaipèdos krašte ir, matyt, vis dar prisimindama kaizerinès okupacijos negandas, savotiškai skandalingą E. M. Remarko kūrinio ekranizaciją, sprendžiant iš žiniasklaidos informacijos, sutiko su beveik neslepiamu piktdžiugišku pasitenkinimu, nors vèliau ị viešumą iškilo ir viena kita kritiška nuomoné ${ }^{58}$. Žinoma, Berlynas

\footnotetext{
55 [reklaminis skelbimas] // Lietuvos aidas, 193103 27, p. 4.

56 A., „Vakarų fronte nieko naujo“ Kaune // Lietuvos aidas, 193103 24, p. 5.

57 Recenzentas straipsnyje taikliai pastebejo: „Jei karo pasmerkimo, taikos idèja vokiečių nacionalistus ịžeidžia, tai, ko gero, jie gali laikyti ịžeidimu ir Nobelio taikos premiją a. a. Strezemanui“ [Gustav Stresemann (1878-1929 m.) - Vokietijos kancleris ir užsienio reikalų ministras (1923-1929 m.), 1926 m. apdovanotas Nobelio taikos premija]. A., „Vakarų fronte nieko naujo“ Kaune // Lietuvos aidas, 193103 24, p. 5.

58 Pasak vieno tautininkų pažiūrų kritiko, „Remarko veikale aiškiai matyti ir raudonu siūlu per visus puslapius eina antimilitaristine tendencija su kosmopolitiškumo raugu, kas užmuša, gal ir netiesiogiai, nacionalinị karžygiškumą, norą pasiaukoti tèvynei, o žuvusiųjų kautynių lauke kultą lyg ir išniekina“. Žr.: Žukauskas J. [recenzija], Beletristika. W. T. Scanlon’as, „Dieve, pasigailèk mūsų!“ Didžiojo karo apysaka. Vertẻ Petras ir Kostas Jurgèlos (Jurgelevičiai), Marijampole, 1934, p. 400, kaina 4 Lt // Vairas, 1934, Nr. 5, p. 116. Gen. št. mjr. Vytautas Bulvičius ị šios Remarko knygos ekranizacijos Holivude priežastis pažvelgè giliau, iškeldamas dvejopų standartų problemą informacinio karo kontekste. Šis įžvalgus karininkas buvo linkęs iš dalies pateisinti vokiečių pretenzijas. Pasak Bulvičiaus, „didžiųjų valstybių organai, norèdami parodyti savo pacifistinę nuotaiką, kartais
} 
diplomatiniais kanalais reiškè nepasitenkinimą tuo, kad Lietuvoje buvo sudarytos sąlygos Pirmojo pasaulinio karo laikų kaizerio kariuomenès ir jos vadovybès „juodinimui“. Tačiau tik Klaipėdoje, veikdama per autonominius valdžios organus ir vietos revanšistus, Vokietija pasieké, kad filmo demonstravimas būtų nutrauktas ${ }^{59}$. Tiek politinių aistrų sukèlusi ekranizacija ịžiebė naują ne tik romano „Vakarų fronte nieko naujo“, bet ir kitų i jị siužetu labai panašių literatūros kūrinių populiarumo pliūpsnị. Antai ketvirtojo dešimtmečio pradžioje tokiu sugretinimo principu Lietuvos spaudoje buvo gana plačiai reklamuojama amerikiečių autoriaus V. T. Skanlono (W. T. Scanlon) apysaka „Dieve, pasigailèk mūsų!“, kurią i lietuvių kalbą išvertė Petras ir Kostas Jurgèlos (Jurgelevičiai) ${ }^{60}$. Be to, lietuviškoje bulvarinèje spaudoje netgi skelbta, kad Remarkas savo romane naudojosi kur kas anksčiau labai kukliu tiražu išleista, todèl plačiau nežinoma vieno lietuvių kilmės autoriaus parašyta knyga ${ }^{61}$. Ir tai ne vienintelis atvejis, kai suabejota šio garsaus rašytojo moraliniu autoritetu. Būta straipsnių, kuriuose jis parodytas kaip prabangų gyvenimą pamégusi, nuolatinio dèmesio savotiškai išlepinta asmenybe $\dot{e}^{62}$.

Taigi vaizdiniai Pirmojo pasaulinio karo tematika Lietuvos, kaip ir kitų šalių, kurias jis paliete, žiniasklaidoje, menininkų kūryboje tarpukariu sukosi ir pynèsi nuolat - gal tik kiek blankiau, provincialiau. Vis dèlto tai stiprino bendros Europos istorijos pajutimą, primindavo apie taikos trapumą

finansuoja pacifistinių filmų gamybą ir aukština rašytojus pacifistus, ypač tuos, kurie apie numatomųjų priešų militarizmą rašo. Tiesa, vienos rūšies pacifistų vyriausybès ir generaliniai štabai nemėgsta - būtent tų pacifistų, kurie ima neigiamai rašyti apie savo valstybės kariuomenę, savos valstybès imperializmą ir militarizmą. Šiuos, savaime aišku, laiko savo galių silpnintojais. Tačiau apie kitas kariuomenes, kitų valstybių imperializmą rašyk, kiek tik nori, skleisk pacifizmą, kiek tik patinka“. Bulvičius V., Karinis valstybès rengimas, Kaunas: Kariuomenès štabo spaudos ir švietimo skyrius, 1939, p. 14.

59 G. V. [Valentinas Gustainis], Kodèl Klaipėdoje uždrausta „Vakarų fronte nieko naujo“ // Lietuvos aidas, 193105 22, p. 7.

60 [Reklaminis skelbimas viršelio vidineje puseje] // Naujoji Romuva, 1934, Nr. 163.

61 Antai teigta, kad Remarkas siužeto kompoziciją, stilistiką nusižiūrèjo ir net iš dalies nukopijavo nuo 1912 m. Hamburge vokiečių kalba išleistos knygos Das Menschenschlachthaus („Žmonių skerdykla“), kurią parašè iš Gumbinès kilęs mažlietuvis Vilius Lamšus, mokytojavęs Hamburge. Žr.: Lietuvis - Remarko pirmtakūnas // Sekmadienis, 193407 01, p. 6.

62 Kaip dabar gyvena „Vakarų fronte nieko naujo“ autorius Remarkas // XX amžius, 193711 12, p. 6. 
ir jos kainą ${ }^{63}$. Kita vertus, tos iš užsienio Lietuvą pasiekiančios antikarinès nuotaikos neturèjo rimtesnès institucinès ir organizacinès paramos.

\section{TARPUKARIO LIETUVOS PACIFISTAI: TARP ILIUZIJŲ IR DEMAGOGIJOS}

Nors taikos iniciatyvos tarptautinèje arenoje, iškiliųjų humanistų antikarinès idejos XX a. trečiojo, o ypač ketvirtojo dešimtmečio oficiozinèje Lietuvos spaudoje buvo vertinamos ganètinai palankiai, ị pacifizmo, arba nusiginklavimo, šauklius šalies viduje žvelgta ịtariai ir dažniausiai priešiškai. Šiame skyriuje pabandysime tai pailiustruoti ir pakomentuoti.

Bet prieš imantis savo pagrindinio siekio, pirmiausia tenka trumpai aptarti didelę ịtaką lietuvių visuomenei turëjusios Katalikų bažnyčios požiūrị i karą. Apmąstant ịvairius pasaulio istorijos pavyzdžius susidaro ìspūdis, kad religinès kilmès (nebūtinai krikščioniškas) pacifizmas pasižymi bene didžiausiu tvarumu, o neretai ir kategoriškumu. Dèl to jis dažnai sulaukdavo išskirtinio valdžios ar kitų organizuotų oponentų spaudimo. XX a. pirmosios pusés lietuviškoje publicistikoje pozityvistai ir marksistai nepraleisdavo progos igelti dvasininkijai dèl to, kad jos hierarchai vienareikšmiškai nepasmerkia karo, prievartos, neatsiriboja nuo valstybès galios struktūrų, taip esą absoliučiai pamindami Kristaus mokymą apie artimo meilę, gailestingumą, neịkainojamą žmogaus gyvybès vertę. I tokius aiškiai angažuotus kaltinimus tekdavo kantriai atsakinèti.

Tarpukariu buvo paskelbta bent keletas didesnès apimties straipsnių ${ }^{64}$, kuriuose gana išsamiai gvildenta karo moralumo problema. Juos

\footnotetext{
63 Kairiųjų pažiūrų rašytojas Antanas Venclova po apsilankymo vienoje iš baisiausių Didžiojo karo mūšių Vakarų Europoje vietoje - Verdene 1937 m. viename savo straipsnyje taip išliejo ten jị užplūdusias emocijas: „Ir supratau, kad juo didesnis būrys bus tų, kurie reikalauja taikos, jai dirba ir ja dieną naktị rūpinasi, tuo Verdeno laukai bus toliau nuo mūsų, tuo jie su savo kapais, su savo bauginančiais šešèliais vis labiau nugrims ị praeitị. Europa iškankinta, sužalota, sudaužyta, sukruvinta. Dvi dešimtys taikos metų anaiptol neužgydẻ kruvinų žaizdų, tos žaizdos ligi šiol alma, pūliuoja. “Žr.: Venclova A., Mirties laukai ties Verdenu // Šalys ir žmonès, Vilnius: Vaga, 1972, p. 50.

64 Kuronieitis A. [Jakštas A.], Antimilitarizmas Lietuvoje // Draugija, 1922, Nr. 5-6, p. 233-237; Būčys P. P., Kariuomenè, tauta, žmonių giminė // Židinys, 1935, Nr. 7, p. 3-11; Yla S., min. str., p. 8; Česaitis I., Karas ir moralè // Mūsuz žinynas, 1938, Nr. 4, p. 548-573.
} 
parašè autoritetingi teologai, katalikų intelektualai. Kai kurias jų mintis prasminga perteikti. Vienas pirmųjų dar XX a. trečiojo dešimtmečio pradžioje konkrečiai ši klausimą svarstyti èmèsi kunigas Aleksandras Dambrauskas-Jakštas (1860-1938 m.) - iškilus katalikiškosios spaudos organizatorius, publicistas, visuomenininkas. Gerai valdąs plunksną, pasižymintis plačia erudicija ir matematiko logika dvasininkas galejo argumentuotai atremti suprimityvintus priekaištus. Savo publikacijoje, pasitelkęs pavyzdžius iš Šventojo Rašto, jis parodè, kad Dekalogo (konkrečiai penktojo Dievo ịsakymo - „Nežudyk“) nuostatų negalima suprasti tiesmukai - būtina suvokti kontekstą, iš kurio ir kyla išimtys. Esminè iš jų - teisė gintis nuo užpuolimo. Šio universalaus dar šv. Augustino suformuluoto principo būtina igyvendinimo priemonè yra sava kariuomenè. Kartu A. Dambrauskas-Jakštas paprastai, bet emociškai paveikiai paaiškino, kodèl Lietuvai pacifistinès iliuzijos nieko, išskyrus tautos ir valstybès pražūtí, negali duoti:

„Karo pavojus, lyg Damoklo kardas, nuolat ant mūsų kabo. Mūsų nepriklausomybè, mūsų žemès reforma baisiai nepatinka mūsų stipresniems imperialistams kaimynams. Jie griežia dantis ir laukia tik progos visą Lietuvą pasiglemžti. Pavojus didelis, visiems aiškus. Vien tik mūsų antimilitaristai to nemato. Jie net šioje kritiškoje valandoje drịsta kelti klausimą: ar jie nenusikals žmogžudyste, jei kovoj užmuš priešą? Ar ne geriau būtų šovus ị orą, užuot ị ginkluotą užpuoliką!.. O Sancta lituana simplicitas! Užpuolikas tų skrupulų neturès, jis drąsiai šaus jiems ị kaktą ir stengsis kuo daugiausiai „prakeiktų lietuvių“ mūšio lauke pakloti!.. Apsimąstykit, ponai antimilitaristai, kol yra laiko! Tai ne Kristaus mokslas, kurị jūs šnekat, bet išgverusio senio Tolstojaus. Per vien laikyti savo skriaudžiamuosius brolius ir jų užpuolikus yra tas pats, kas per vien laikyti Kristų ir Barabą. "“5

Panašiai, taikydamas ị jautriausią skaitytojų širdžių vietą, Lietuvos teisę ginti savo teritoriją ir nepriklausomybę $1935 \mathrm{~m}$. kultūros žurnale „Židinys“ išspausdintame straipsnyje įrodinejjo vyskupas Petras Pranciškus Būčys: „Užimdama Vilnių, Lenkija padarè mums skriaudą, suardè visuotinę tvarką ir teisybę. Karas visuotinei tvarkai ir teisybei atstatyti yra taip pat teisètas ir doras, kaip ir karas tai tvarkai apginti. "66 Argumen-

${ }^{65}$ Kuronietis A. [Jakštas A.], min. str., p. 236-237.

${ }^{66}$ Būčys P. P., min. str., p. 8. 
tas - labai stiprus. To meto lietuvių visuomenei Vilniaus kraštas buvo „šventas“ - tokiu turejjo tapti ir galimas karas dèl jo.

1938 m. „Mūsų žinyne“ išspausdintame straipsnyje kunigas Ignas Česaitis ragino tiesmukai nesuprasti ir nesuabsoliutinti tezès, jog „dorovinè Evangelijos doktrina skelbia tautoms taiką ir santarvę", nes Evangelija „atvirai pripažizsta ir karių profesijos teisètumą "67. Jis pažymèjo, kad, siekiant apginti nuo užpuolimo, išsaugoti taiką, tenka ruoštis arba net naudoti ginklą. Ne vieną skaudžią Didžiojo karo istorijos pamoką gavusios valstybès labiau nei bet kada iki tol naudojasi kiekviena proga taikos siekiams deklaruoti, tačiau, nepaisant to, nepasitiki viena kita, abejoja tarptautinio arbitražo efektyvumu, todèl neketina atsisakyti kariuomenès, ruošiasi galimus konfliktus spręsti jèga. Rūsčios realybès esą nenori suprasti tik „kraštutiniai pacifistai“ - įvairios „mistiškosios sektos“, Tolstojaus šalininkai, „masoniškojo humanizmo teoretikai“, socialistai. Jų nuostatos - utopinès. Savo straipsnị I. Česaitis baigè vienareikšmišku priesaku: „Krikščioniškos dorovès vardu galime reikalauti, kad būtų veikiama prieš karą, kad kiekvienas darytų kas galima taikos naudai, bet nevalia piliečiui atsižadèti savo vaidmens, jei vieną dieną kraštas būtų verčiamas kariauti. "68 Labai palankiai apie kariuomenès reikšmę valstybèje, karo tarnybą atsiliepè ir pagrindinis tuo laikotarpiu lietuvių tautos ugdymo vizijos kūrèjas, visuomenės moraliniu autoritetu laikytas profesorius Stasys Šalkauskis ${ }^{69}$.

Reziumuojant katalikų publicistų požiūrị ì pacifizmą reikia konstatuoti, jog jis pasižymejjo subalansuotumu, gyvenimiškumu. Buvo remiamos taikos iniciatyvos tarptautineje arenoje, nes jomis rūpinosi abu tarpukario laikotarpio popiežiai - Pijus XI ir Pijus XII ${ }^{70}$, bet kartu pripažinta ir valstybès teise gintis ir stiprinti savo gynybos priemones. Pusiau rimtai pasižiūrèjus, pacifizmo ribas katalikams savotiškai ženklino vien jau faktas, kad ir pats Vatikanas turẻjo savo simbolinę gvardiją.

Dvasininkų, teologijos žinovų komentarai buvo labai reikšmingi moraline prasme, pagrindžiant ginkluotųų pajègų stiprinimo, tautos karinio

\footnotetext{
67 Česaitis I., Karas ir moralè // Mūsų žinynas, 1938, Nr. 4, p. 549, 550.

68 Ten pat, p. 573.

69 Šalkauskis S., Kariuomenè, kaipo tautos ugdymo veiksnys // Židinys, 1935, Nr. 7, p. $12-18$.

70 Kasparavičius A., Tarp politikos ir diplomatijos: Šventasis Sostas ir Lietuvos Respublika, Vilnius: Lietuvos istorijos instituto leidykla, 2008, p. 452.
} 
rengimo siekius. Sykiu tai leido viešumoje ịtikinamai marginalizuoti tuos, kuriems taikus sambūvis tapo besąlygiška dogma. Kaip idejjiniai pacifistai tarpukario Lietuvos spaudoje pirmiausia yra įvardijami rusų rašytojo L. Tolstojaus šalininkai ${ }^{71}$, bet konkrečios informacijos apie juos labai mažai ${ }^{72}$. Paprastai būdavo pažymima, kad tai esanti savotiška sekta, išpažǐstanti nesipriešinimo blogiui jèga principą, pasisakanti prieš kariuomenę, politinès galios siekimą, propaguojanti krikščionišką artimo meilę, dorovinị tobulinimąsi, asketišką gyvenimą. Tokios nuostatos buvo gana artimos katalikybei, tačiau šios konfesijos dvasininkai L. Tolstojaus mokymą laikè erezija ir jokio palankumo jam nerodè. Dar daugiau - net ị intelektualią publicistiką kartais prasprūsdavo pagiežingas subjektyvizmas. Kaip iliustraciją galima pateikti čia jau pacituotą A. Dambrausko-Jakšto poziciją. Bet būta ir dar piktesnių epitetų. Antai kunigas Stasys Yla viename savo straipsnių rèžè toki verdiktą: „Reikalaudamas nesipriešinti piktam, tolstojizmas toleruoja piktos valios triumfą, anarchiją ir dèl to prilygsta komunizmui. “73

Be tolstojininku, XX a. trečiojo dešimtmečio provyriausybinèje ir katalikiškoje spaudoje kartkartèmis minèti ir kiti - ne dèl religinių priežasčių „pacifistinèms iliuzijoms“ pasidavę „nesubrendèliai“ ir „svajotojai“ - legalių kairiųjų partijų ir jaunimo organizacijų nariai, „bedieviai“ mokytojai, dèl savo komforto besibaiminą „savanaudžiai miesčionys“ bei

71 Valstybès Prezidentas kariuomenès ir visuomenès susiartinimo dienos proga „Lietuvos aidui“ rašo // Lietuvos aidas, 193505 25, p. 1.

${ }^{72} \mathrm{Ne}$ tik to meto spaudoje, bet ir ligšiolinèje istoriografijoje žinios apie Lietuvos tolstojininkus gana fragmentiškos. Žinoma, jog jų èmė rastis jau XIX-XX a. sandūroje. Iki Antrojo pasaulinio karo tokiais „keistuoliais“ daugiausia garsèjo Šiaulių kraštas, nors buvo jų ir apie Panevėži, Kèdainius. Žymiausiais tolstojininkais Lietuvoje laikomi Andriejus Kalendra (1885-1952 m.), gyvenęs Šiauliuose, paskui Kruopiuose (dabartiniame Akmenès rajone), Edvardas Levinskas (1893-1975 m.), mokytojavęs Šiauliuose, Joniškyje ir netoli jo esančioje Žagarejje. Pastarasis rūpinosi L. Tolstojaus raštų vertimu, laikraščiu leidyba. Šiame bare dirbo ir kiti. Pavyzdžiui, L. Tolstojaus veikalą „Pirmoji pakopa“ išvertė Mikalojus Kuprevičius (Kuprevičius G., Koncertas: Tyto alba, 2014, p.16). Nepriklausomoje Lietuvoje vieša tolstojininkų veikla buvo šiek tiek pastebimesnè tik iki XX a. trečiojo dešimtmečio vidurio. 1922 m. jie trumpai leido laikrašti „Meilès keliais“, 19231924 m. - „Atgimimą“. Laisviau jaustis tolstojininkams trukdè ir katalikų dvasininkijos priešiškumas, ir padidintas teisèsaugos dèmesys dèl, kaip manyta, antivalstybinių pažiūrų skleidimo. Žr.: Masionienė B., Tolstojystė Lietuvoje // Problemos, 1970, Nr. 6, p. 74-82.

73 Yla S., Krikščioniškasis pacifizmas. Karo ir taikos problemos pagrindai // XX amžius, 19361223 , p. 8. 
šiaip įvairūs keistuoliai. Viešojoje erdvèje lietuviškieji pacifistai tarsi virto kažkokia beforme abstrakcija, kuriai prireikus galejo būti priskirti visi, pasisakantys prieš Lietuvos kariuomenès stiprinimą, visuomenès karinio rengimo užmojus. Jų pavardžių nenorèta „reklamuoti“. Išimčių - labai nedaug. Pavyzdžiui, 1922 m. viename katalikiško laikraščio „Draugija“ straipsnyje kaip vienas ryškesnių antimilitarizmo šauklių ịvardytas poetas Butkų Juzė (t. y. Juozas Butkus) ${ }^{74}$ - tai tuo metu buvo visiems aiški nuoroda ị keturvejjininkų sambūrị. Panašiomis progomis taip pat mègta postringauti, jog tokių veikèjų Lietuvos padangeje atsiranda todèl, kad visuomenę, ypač inteligentiją, „tvirkina“ ịvairi žalinga filosofinè ir politinė literatūra, kaip teigta, be rimtesnių kliūčių plūstanti ne tik iš Rytų, bet ir iš Vakarų. Kaune esą buvo gana populiarūs kai kurie antikarinès pakraipos vokiški ir prancūziški laikraščiai ${ }^{75}$. Vakarietiškąji pacifizmą smarkiai viename savo rašinių „sutaršè “ socialinio kritiko vaidmens spaudoje nevengęs matematikas ir fizikas, VDU docentas Paulius Slavėnas. Jis išskyrė dviejų tipų pacifizmą: 1) skleidžiamą didžiųjų valstybių propagandistų, kurie taikos ideja veidmainiškai dangstè savo šalies imperialistinius tikslus, o militarizmu kaltino kitas, pirmiausia potencialias, priešininkes, ir 2) individualistinị. I pastarąji publicistas pažvelgè nebūdingu tiksliųjų mokslų atstovui kampu, šio įsitikinimo prigimtį aiškindamas demokratinès Europos „moraliniu pakrikimu“. Pasak Slavėno, „bevaikès prancūzų šeimos yra visiems žinomas statistikos faktas. Nedaug kuo skiriasi ir Anglija. Būtent Londone krenta $\mathfrak{i}$ akis nepaprastas senmergių, senbernių ir kambarinių šunų gausumas“. O tai ir esanti problemos esmé, nes „visokie antišeimyniniai gaivalai yra pagrinde asocialūs ir egoistiški, bet kartu su tuo jie pakankamai landūs ir veiklūs visuomenejje veikti. Savo egoizmą, savo kailiu susirūpinimą ir žmonių neapykantą šitokie tipai, filosofiškai tariant, apipavidalina šunų globa ir pacifizmu"76. Tokį taikingumo garbinimą autorius ragino „rauti su šaknimis“, nes „kultūra, kuri veda prie ištižimo ir kapituliacijų, nèra kultūra, bet rafinuota demoralizacija“"77.

\footnotetext{
74 Kuronietis A. [Jakštas A.], min. str., p. 234.

75 Bučys P. P., Kariuomenè, tauta, žmonių giminė // Židinys, 1935, Nr. 7, p. 4.

76 Slavėnas P., Mums reikia išmokti patogiai gulèti ir po Damoklo kardu. Psichologinis karas. Karinè propaganda ir kultūrinis darbas. Pacifizmas ir brangesnès už taiką idejjos // XX amžius, 193904 15, p. 3.

77 Ten pat, p. 3.
} 
Pacifizmo fenomeną analizuoti bandè ir gen. št. mjr. Vytautas Bulvičius - tragiško likimo asmenybè, vienas iškiliausių tarpukario Lietuvos karininkų mąstytojų. Savo konceptualioje knygoje „Valstybès karinis rengimas“, be kitų temų, pateikdamas savo ižvalgas apie „pacifistus antimilitaristus $^{\text {"78 }}$, jis pažymejjo, kad tai - sąlyginè grupé, turinti ịvairių atmainų. Autorius išskyrè ir apibūdino dvi esmines pacifistų rūšis - teoretikus ir praktikus ${ }^{79}$. Teoretikai - ignoruojantys plèšrūniškus žmogaus instinktus, vienareikšmiškai atmetantys bet kokią ginkluotą prievartą kaip absoliutų blogị, tačiau negalintys pasiūlyti jokių realių būdų tai utopinei idilei pasiekti; praktikai - tai kovotojai už visuotinę taiką, savo tikslo siekiantys veikdami ịvairiose tarptautinèse struktūrose, inicijuojantys tarpvalstybinio arbitražo, žmogaus teisių apsaugos, nusiginklavimo konferencijas ir sutartis ${ }^{80}$. Pirmuosius V. Bulvičius vertino neigiamai ${ }^{81}$, antruosius - iš esmès palankiai, nes jie savo kilnaus tikslo siekè racionaliai,

78 Bulvičius V., Karinis valstybès rengimas, Kaunas: Kariuomenès štabo Spaudos ir švietimo skyrius, 1939 , p. 12-15.

79 Kitas lietuviškos kariškos minties atstovas spaudos baruose - Balys Vosylius antikarinių nuostatų žmones taip pat skirstė ị dvi grupes - „sąmoninguosius“ ir „nesąmoninguosius“, bet tam skirstymui pasirinko kiek kitokị nei V. Bulvičius principą. „Sąmoningieji pacifistai“ - priešiški kariuomenei, nes suvokia galimus karo veiksmų padarinius, o Lietuvos atveju dar ir mano, kad mažos šalies kova su didesniais agresoriais gali būti visiškai beviltiška. „Nesąmoningųjų“ pacifistų laikyseną lemia ginklų ir kitų karo atributų baimè - jie nenori ar nepajègia pripažinti žiaurios konfliktų tarp žmonių tikrovès. Vosylius B., Karinis visuomenès auklèjimas // Mūsǔ žinynas, 1937, Nr. 6, p. 677-678.

80 Taip apibrèžiama praktinio pacifizmo sąvoka politologineje literatūroje vartojama iki šiol. Kaip pavyzdi galima pateikti šiam reiškiniui skirtą Endriu Fialos (A. Fiala) knygą. Beje, tai, ką V. Bulvičius apibūdino kaip teorinị pacifizmą, E. Fiala vadina absoliučiuoju pacifizmu (religinèmis, metafizinèmis nuostatomis pagrịstą visišką karo ir prievartos atmetimą). Žr.: Fiala A., Practical Pacifism, New York: Algora Publishing, 2004, p. 8. Sendis E. Kuperis (S. E. Cooper), nagrinèjęs Vakarų Europos pacifistų praktikų pastangas sustabdyti žmonijos ritimąsi ị Didijj karą, šios jų veiklos kilnumui išryškinti pasirinko „patriotinio pacifizmo“ pavadinimą. Žr.: Cooper S. E., Introduction // Patriotic Pacifism: Waging War on War in Europe 1815-1914, Oxford: Oxford UP, 1991, p. 5.

81 Būtina pabrèžti, kad V. Bulvičius kritiškai vertino ne tik besąlygiškąji pacifizmą, bet ir tokio pat pobūdžio militarizmą. Žr.: Bulvičius V., min. veik., p. 324. Savo vizijoje piliečio šalies gynejo pareigą jis siekè kuo labiau humanizuoti, pabrěždamas būtinybę Lietuvos kariams skiepyti riteriškas, t. y. garbingos kovos, manieras. Karininkas vylèsi, kad „Lietuva kariaus tik užpulta, kai kitos išeities nebebus, o „tarptautinę teisę laužysime tik tuomet, jei ją priešas laužys. Kare, kur tik galèsime, visur įnešime žmoniškumo dvasios, kur tik galèsime, naikinsime aklos neapykantos dvasią“ (p. 326). 
blaiviai vertindami situaciją ${ }^{82}$. Karininkas netgi atidavė jiems savotišką duoklę, savo knygoje propaguodamas kai kuriuos praktinio pacifizmo principus. Pavyzdžiui, ragindamas ruoštis karui, sykiu jis akcentavo būtinybę remti racionalias taikos šalininkų pastangas („visur, kur tik matome žmonijos gyvenime pragiedrulių, juos turime sveikinti, stiprinti“" ${ }^{83}$. Kitaip tariant, einamieji gynybiniai reikalai neturètų visiškai išsklaidyti vilčių dèl visuotinès taikos idealo, kuris galbūt bus igyvendintas kada nors tolimoje ateityje.

O štai teoretikams kandaus, bet vaizdingo žodžio V. Bulvičius nepagailèjo: „Tokios rūšies pacifistai kaip Remarkas nesiūlo jokio plano karams išvengti ir turbūt negalvoja apie kokị nors planą. Tokie žmonès kiek primena nihilistus, kurie viską kritikuoja, visas blogybes nurodinejja, bet ką nors praktiško padaryti, kad tų blogybių nebūtų, nesugeba. O jeigu ir pasiūlo ką nors, tai tas pasiūlymas dažniausiai ne žemei, bet dangui pritaikytas ir aiškiausiai neịvykdomas. Jų pasiūlymai kaip ir galvojimas eina iš jausmų. " ${ }^{84}$ Pacifistų teoretikų idealizmas, pasak Bulvičiaus, vargiai galètų kelti simpatijas dar ir dèl to, kad jie, skirtingai nuo daugumos militaristų, save laikẻ beveik šventaisiais, puikuodavosi ginantys neginčijamą tiesą ${ }^{85}$. Ir teorinis, ir praktinis pacifizmas plito iš tam tikrų globalių židinių.

Savo knygoje V. Bulvičius nurodè svarbiausias tarptautines organizacijas ir neformalias jègas, vienaip ar kitaip jas „spinduliavusias“. Tai - Katalikų Bažnyčia, Tautų Sąunga, Hagos tarptautinis tribunolas, Kominternas, masonų ložès, „Rotary“ klubas, Raudonasis Kryžius. ${ }^{86}$ Kitas šią temą palietęs autorius - teisininkas Martynas Kavolis prie jų dar priskyrè ir tarptautinị moterų judejjimą ${ }^{87}$. Pažymètina, kad V. Bulvičiaus sąraše nèra nurodytas Paneuropos projektas, nors pacifistinès vizijos jame užèmé centrinę vietą. Greičiausiai, nenorẻdamas leistis ị detalesnị aptarimą, šị

\footnotetext{
82 Ten pat, p. 324.

83 Ten pat, p. 326.

84 Ten pat, p. 14.

${ }^{85}$ V. Bulvičius pabrèžè, kad Lietuvos jaunimą mokyklose reikètų supažindinti su abiem kraštutinumais - pacifizmu ir militarizmu, tačiau ši informacija turètų būti pateikiama kritiškai. Tai esą padètų susiformuoti sveikam požiūriui ị savo šalies gynybos reikalus.

86 Bulvičius V., min. veik., p. 18.

87 Kavolis M., min. str., p. 404-405.
} 
internacionalą autorius priskyrè masonų kategorijai. Padarius šią prielaidą dar būtina pridurti, jog minètas tarptautinis judejjimas nebuvo kažkas tolima ir egzotiška - jis turejjo filialą ir Lietuvoje - nuo XX a. ketvirtojo dešimtmečio pradžios Kaune veikè atitinkamas intelektualų klubas. Jo nariais tapo žinomi lietuvių akademinio ir visuomeninio elito žmonès, tarp kurių pirmiausia paminėtini Vincas Čepinskis, Valentinas Gustainis, Vladas Kurkauskas, Juozas Purickis, Mykolas Romeris, Jonas Vileišis ir Zigmas Žemaitis. Šis sambūris 1932 m. lietuvių kalba išleido žymiausio Senojo žemyno tautų taikaus sambūvio ideologo grafo R. N. KudenhoveKalergi knygą „Pan-Europos $\mathrm{ABC}^{\text {“88 }}$. Tai, atrodo, buvo pati įtakingiausia adekvačiųjų pacifistų „praktikų“ grupe tuometeje Lietuvoje. O nihilistinès pakraipos „teoretikų“ atstovais, ko gero, reiketų laikyti kai kuriuos legaliai besireiškusius kairiuosius visuomenininkus ir kultūrininkus, aiškinusius, jog valstybè kariuomenei tenkančias lèšas turètų skirti švietimui ir kultūrai.

Tokias idejjas skleidè ir jaunimo karinio parengimo siekius ketvirtajame dešimtmetyje nuosekliai kritikavo žurnalas „Mokykla ir visuomenë“. Jo redakcinę politiką atitinkama vaga kreipè Vytauto Didžiojo universiteto profesoriai Pranas Augustaitis ir Antanas Purènas ${ }^{89}$. Panašių nuostatų laikèsi ir tam tikra dalis žemesnio rango pedagogų, kuriuos sovietinė istoriografija vèliau „pagerbe்“ „antifašistų“ arba „pažangiųjų“ mokytojų vardais. Ne visi iš jų, bent jau tuo metu, buvo susiję su komunistiniu pogrindžiu, kurio propagandoje antikarinė demagogija užèmė išskirtinę vietą. Lietuvos spaudoje legalieji kairiosios pakraipos antimilitaristai yra gana aiškiai atskiriami nuo komunistų. Pirmieji laikomi paklydèliais, antrieji „antivalstybiniu gaivalu“, kuris sąmoningai siekè susilpninti visuomenès paramą šalies nepriklausomybę ginti turinčiai kariuomenei. Iš Maskvos valdomi Lietuvos komunistų partijos agitatoriai kiekviena pasitaikiusia proga skelbė taikingus Sovietų Sąjungos - „viso pasaulio proletariato tèvynès“ - siekius, ragino priešintis kapitalistų ir fašistų militarizmui, imperialistinio karo kurstymui. Tai buvo pati skambiausia pasaulinei publikai skirta sovietų propagandos gaida, nenusilpusi visą didžiąją XX

88 Kastanauskaitė L., min. veik., p. 103.

89 Ažubalis A., Kazlauskaitè-Markelienè R., Žilènienè V., Karinis rengimas Lietuvos mokykloje (1929-1940 m.), Vilnius: Generolo Jono Žemaičio Lietuvos karo akademija, 2009, p. 149. 
amžiaus dali. Jos patrauklumą ir veiksmingumą Rusijos bolševikų vadai suprato labai anksti. Kaip pažymejjo Aleksandras Štromas, neatsitiktinai vienas pirmųjų iš trijų Lenino vyriausybès dekretų (1917 m. spalio $28 \mathrm{~d}$.) buvo skirtas taikos klausimuii ${ }^{90}$ Komunistai šia stipria „korta“ norèjo lošti vieni ir visaip stengèsi diskredituoti konkurentus, pirmiausia Maskvai nepavaldžius demokratinès orientacijos kairiuosius. Prieita netgi iki to, kad 1928 m. šeštajame Kominterno kongrese visa socialdemokratu veikla buvo paskelbta socialfašizmu. Lietuvos pogrindininkai irgi gavo atitinkamus ịsakmius nurodymus. Stebina ne tik atvirai pagiežingas jụ tonas, bet ir keista vidine logika: „Kova prieš karo pavojų iškelia būtiną reikalą atvirai ir negailestingai kovoti prieš socialdemokratiją, prieš visokius „pacifistinius“ melagingus mokslus, kad ir kažin kokiais antraštėliais ir iškabomis jie būtų patiekiami. Komunistai turi atkakliai ir sistemiškai sklaidyti visokių rūšių pacifistinius rūkus. ${ }^{\text {"91 }}$ Tokios priešiškos nuostatos laikytasi iki pat ketvirtojo dešimtmečio vidurio, kai Kominternas iškèlè uždavinį suburti „antifašistinius liaudies frontus“ iš kuo platesnių visuomenès sluoksnių - tada prakeiksmų socialdemokratų adresu atsisakyta. Lietuvos spauda (net ir kairiosios pakraipos) sovietų deklaruojamus taikos siekius vertino skeptiškai ${ }^{92}$.

Veidmainišką Kominterno ir jo agentų visame pasaulyje skleidžiamą pacifistinę propagandą Lietuvoje vienas pirmųjų įstabiai demaskavo teisininkas ir istorikas Augustinas Janulaitis ${ }^{93}$. Pats būdamas socialdemokratinių pažiūrų nuoširdus humanistas, jis, atrodytų, natūraliai turèjo tapti kairiojo antimilitarizmo, plačiai vešejjusio XX a. trečiojo dešimtmečio Europoje, šalininku ir galbūt net skelbejju. Tačiau gilus analitinis protas, gyvenimiška patirtis ir Rusijos pažinimas neleido jam „susirgti“ šia „pažangaus teisuoliškumo“ liga, kuri akivaizdžiai kamavo kai kuriuos Steigiamojo ir trijų vèlesnių seimų socialdemokratų frakcijos narius.

\footnotetext{
90 Shtromas A., The Soviet Union and the Politics of Peace // West European Pacifism and the Strategy for Peace, ed. P. Van den Dungen, New York: Palgrave Macmillan, 1985, p. 130.

91 Komunistinio internacionalo kova su karo pavojumi // Komunistas, 1929, Nr. 1, p. 19. 92 Žr. pvz.: Sovietų pacifizmo priežastis //Lietuvos žinios, 193410 25, p. 1; P. N., Militarizmas: Atgal ị viduramžius // Lietuvos žinios, 193410 31, p. 3.

93 Janulaitis A., Lietuva ir dabartine Rusija. Kas tai yra dabartine Rusija, kas ir kaip ja valdo, ir ką Lietuva iki šiol iš jos turèjo, ir ko gali laukti, Kaunas: Raidè: 1925, p. 32-33.
} 
Nemažiau konceptualiai Sovietų Sąjungos taikos propagandos veidmainiškumą savo 1937 m. išleistoje knygoje „Komunizmas Lietuvoje“ atskleide kunigas S. Yla. Aštuntąji veikalo skyrių jis pavadino „Pacifistinè ir antimilitaristinė akcija “94. Jame autorius įtikinamai paaiškino, ko Maskva tokia propaganda siekia: suvedžioti taikos trokštančias mases, nuteikti jas prieš savo valstybes, kariuomenes ir taip atverti kelią sovietų ekspansijai, demagogiškai dangstomai liaudies revoliucijų ir internacionalinès pagalbos joms vardais ${ }^{95}$. S. Yla konstatavo, kad Kominterno agentų veikla šia linkme buvo aktyvi ir Lietuvoje. XX a. ketvirto dešimtmečio antroje pusèje susidariusią situaciją jis įvertino taip: „Nors mūsų krašte, atrodo, dar nėra viešai veikiančių komunistų ar jiems artimų pacifistinių organizacijų, tačiau „pacifistinè akcija tyliai ir atsargiai varoma mūsų visuomeneje, ypač liaudyje ir moksleivijoje, tiek žodžiu, tiek raštu. Šita akcija yra nukreipta daugiau antimilitaristine kryptimi ir varoma mūsų kariuomenèje ir kariuomenèn besiruošiančios jaunuomenès tarpe . ${ }^{\text {"96 }}$

Kad tai buvo gana rimta problema, rodo ir faktas, jog ją viešai pripažino pats Respublikos prezidentas Antanas Smetona. 1935 m. gegužę „Lietuvos aidui“ jis teigè: „Ne paslaptis, kad nestinga pakurstų, siekiančių visokiais būdais pakirsti mūsų ginklo pajègą. Tie pakurstos yra mūsų tautos priešai, norintieji iš pasalų sunaikinti jos laisvę. İsiterpę kariuomenèn ar pagal ją slankiodami, jie nori klastingai parausti jos vieningą drausmę. Visuomenė neprivalo kęsti tokių gaivalų, kaip gera šeimininkẻ neapsikenčia piktžolèmis savo darže. Pagedusio gaivalo neturi būti nei kariuomenejje, nei arti jos. Kariuomenè saugo savo kraštą, o visuomenè turi saugoti savo kariuomenę. ${ }^{\text {(97 }}$ Tai buvo esminè priežastis, dèl kurios tuometėje Lietuvoje $\mathfrak{i}$ visas antikarines idejjas ir jas kèlusius sambūrius žvelgta ịtariai, o dažnai ir priešiškai.

\footnotetext{
94 Daulius J. [Yla S.], Komunizmas Lietuvoje, Kaunas: Šviesa, 1937, p. 136-142.

95 Ten pat, p. 136-137.

96 Daulius J. [Yla S.], min. veik., p. 138-139.

97 Valstybès Prezidentas kariuomenès ir visuomenès susiartinimo dienos proga „Lietuvos aidui“ rašo // Lietuvos aidas, 193505 25, p. 1.
} 


\section{MILITARIZMAS IR ANTIMILITARIZMAS LIETUVOS RESPUBLIKOS OFICIALIOJOJE RETORIKOJE}

Pacifizmo refleksijos Lietuvos viešojoje erdvejje XX a. 3-4 dešimtmetyje analizè neįmanoma, nepristačius tuo metu vyravusio požiūrio ị militarizmą, neišsiaiškinus, kaip jị suprato, ką apie ji manė politikai, valdžios pareigūnai ir kariuomenès atstovai.

Lietuvos Respublikos kariuomenè 1918-aisiais kūrèsi labai sudètingomis sąlygomis. Ši procesą komplikavo ne tik specifinè krašto geopolitinė padètis, materialiniai sunkumai, bet ir specialistų bei kariškų tradicijų stoka $^{98}$. Rusijos imperijos kariuomeneje katalikai lietuviai, skirtingai nuo daugiausia liuteronų tikejjimą išpažistančių latvių ir estų, iš esmès negalèjo padaryti karjeros, be to, neturèjo ir savo tautinių dalinių Pirmojo pasaulinio karo metais (nors parodè gana unikalų patriotinio susipratimo ir saviorganizacijos pavyzdį) $)^{99}$. Tarp $1917 \mathrm{~m}$. rugsejjo pabaigoje sudarytos Lietuvos Tarybos narių ir ị ją nepatekusių pradedančiųjų politikų kariškių ar bent kiek glaudžiau susijusiųjų su kariuomene iš esmès nebuvo ${ }^{100}$. Problemišką tuomečio lietuvių politinio elito karinių reikalų neišmanymą, pasak vieno iš aktyviausių Lietuvos kariuomenès kūrèjų Kazio Škirpos, dar labiau aštrino gana paplitusios „nusistatymo prieš militarizmą“ nuotaikos $^{101}$. Iš dalies dèl to 1918-aisiais Nepriklausomybę paskelbusios Lietuvos gynybos organizavimas vyko padrikai, neišvengta klaidų. Bene rimčiausią iš jų padarè pirmoji šalies vyriausybè (1918 m. lapkričio $2 \mathrm{~d}$. gruodžio 26 d.). Ministras pirmininkas prof. Augustinas Voldemaras, ekscentriškas intelektualas, pernelyg kliovèsi tarptautine teise, Antantės

\footnotetext{
98 Vosylius B., Karinis visuomenès auklèjimas // Mūsų žinynas, 1937, Nr. 6, p. 676.

99 Plačiau žr.: Lesčius V., Lietuvos kariuomené 1918-1920, Vilnius: Leidybos centras, 1998, p. 17-59.

100 Tam tikra išimtimi tarp Lietuvos valstybès kūrèjų galètume laikyti Joną Basanavičių, kuris turejo šiokios tokios karo gydytojo patirties, igytos Bulgarijoje XIX a. pab. - XX a. pr.: Basanavičius J., Mano gyvenimo kronika ir nervu ligos istorija 1851-1922 m., Vilnius: Baltos lankos, 1997, p. 121.

${ }^{101}$ Škirpa K., Kariuomenès kūrimo pirmos pastangos ir pirmos kliūtys // Mūsų žinynas, 1938, Nr. 11-12, p. 703.
} 
sąjungininkų gera valia ir tikejjimu, jog pasibaigęs alinantis karas Europoje ilgam sukurs taikingą atmosferą, užtikrins mažų valstybių sienų neliečiamumą. Numatant tokią perspektyvą, Lietuvai kariuomenė apskritai esą turèjo būti nereikalinga - pakaktų vien milicijos vidaus tvarkai palaikyti ${ }^{102}$. Tačiau šios iliuzijos greitai subliūško susidūrus su bolševikų, o paskui su bermontininkų ir lenkų ekspansija. Realios grèsmės akivaizdoje teko formuoti naują, racionaliau susidariusią situaciją vertinančią vyriausybę. Pamoką, kad ginkluota jèga yra daug patikimesnis argumentas už idealistinius lozungus, teko išmokti. Tačiau tai nereiškia, jog 1919-1920 m. apgynus valstybingumą, antikarinès ir tam tikru pavidalu išreikštos pacifistinès nuostatos iš Lietuvos politinių sluoksnių retorikos visiškai išnyko. Bent jau demokratinių seimų laikotarpiu (1920-1926 m.) raginimų apriboti kariuomenès ịtaką valstybeje, mažinti išlaidas pasigirsdavo gana dažnai ir neretai be rimto reikalo - vien kaip pretekstas kairiajai opozicijai padaryti skambų demaršą politineje arenoje nuolatos dominavusiems krikščionims demokratams, kurie, reikia pripažinti, įsijautę $\mathfrak{i}$ ”Dievo palaimintųjų“ vaidmenį, dažnokai nesusilaikydavo nuo pagundų piktnaudžiauti karo padèties ir kitais turimais administraciniais viešojo gyvenimo suvaržymo svertais.

Kairiųjų stovykloje ryškiausiai pacifistiniam požiūriui atstovavo socialdemokratai. Jie nuosekliai laikèsi milicinès kariuomenès idejjos, o karštų debatų Seime metu nevengdavo užsipulti „lietuviškojo militarizmo“. Antai 1922 m. vasario mènesị, svarstant Karo mokyklos projektą, vienas LSDP frakcijos lyderių, profesorius Vincas Čepinskis piktinosi: „Pas mus kai kurie mano, kad nèra militarizmo - daugelis karininkų, daugelis uniformuotų žmonių gatvėse dar nereiškia, kad pas mus viešpatauja militarizmas. Bet aš turiu pasakyti, kad visų tų išorinẻ išvaizda ir, kas svarbiausia, jų elgesys aiškiai rodo, kad pas mus yra militarizmas ir militarizmas blogiausios rūšies, nes viskas, kas pas mus daroma, sulig kurpaliu ne Vakarų Europos <...> bet sulig reakcinès Rusijos kurpaliu. “103

Palaikydamas radikaliausių socialdemokratų nuostatas, dar atviriau priešiškumą kariuomenei reiškè valstiečių ir liaudininkų frakcijos narys Jurgis Žitinevičius. „Mes žinome, kiek toji armija kaštuoja, ir argi galima

\footnotetext{
102 Truska L., Antanas Smetona ir jo laikai, Vilnius: Valstybinis leidybos centras, 1996, p. 90 .

103 Steigiamojo Seimo darbai (toliau - SSD), 192202 03, 167 pos., p. 12.
} 
bus ateityje visą laiką laikyti tokią armiją, kaip ligi šiol turime, aš manau, kad armijos laikymas kenkia labai krašto atstatymui", - iš Seimo tribūnos dèstè jis. J. Žitinevičiaus nuomone, „laikymas nuolatinès didelès armijos tai yra noras turèt visuomet parengtą grūmojamąji kumštị, ir toks militarizmas politiniu atžvilgiu yra nuolatinis pavojus. Dèl to ir reikètų atsisakyti nuo to pavojaus ir sutvarkyti ginkluotąsias pajègas milicijos pagrindais" ${ }^{\text {"104 }}$.

Išlaidų kariuomenei mažinimas tapo vienu svarbiausių socialdemokratų partijos lozungų per 1926-ųjų pavasario rinkimų i Trečiąji Seimą kampaniją. Agitatoriai buvo specialiai instruktuojami, kaip ịtikinamiau pateikti tą "lèšų švaistymo“ problemą masinei auditorijai ${ }^{105}$. Valstiečiai liaudininkai, epizodiškai bendradarbiavę su krikščionimis demokratais, $\mathrm{XX}$ a. trečiojo dešimtmečio pradžioje laikèsi kur kas nuosaikesnès pozicijos. Militarizmo kritikų atsirasdavo net ir tarp valdančiojo krikdemu bloko narių. Pavyzdžiui, $1921 \mathrm{~m}$. pavasarị, aptariant Šaulių sąjungos ịstatymą, Ona Muraškaitė-Račiukaitienè garsiai samprotavo: „Matyt, militarizmo idejja auga ir plečiasi ir pas mus, ir vietoj to, kad ją naikinus ir vijus iš mūsų gyvenimo, mes ją ginam ir platinam; pradedam leisti įstatymus, kad kaip nors dar labiau igudinus žmones, jaunimą i karą, kad jis pamiltų dar labiau vartoti tą ginklą, negu kad šiandien vartoja." ${ }^{106}$

Tiesa, Lietuvos kariuomenè tada buvo gana didelè - joje tarnavo daugiau nei 51 tūkstantis karių ir jai tekdavo apie pusę viso valstybės biudžeto ${ }^{107}$, bet tai lèmé svarios priežastys: vos pasibaigus didžiosioms kovoms dèl nepriklausomybės, niekas negalejo užtikrinti, kad jos vèl neatsinaujins. Jau 1922 m. karių skaičių imta mažinti, pradèta persiorientuoti, prisitaikyti prie taikos meto gyvenimo ${ }^{108}$. Apskritai kariuomenès veiksnys politiniuose šalies procesuose demokratinių seimų laikotarpiu neturëjo tokios reikšmès kaip paskesnius keturiolika autoritarizmo metų. Tačiau ir tada jis ne iš tolo nepasiekẻ tipiško karinių režimų lygio, kur vyriausybė išreiškia ją suformavusių kariškių valią.

${ }^{104}$ SSD, 192204 10, 196 pos., p. 115.

${ }^{105}$ Dagys J., I praeitị atsigręžus. Biržiečio ekonomisto atsiminimai, Kaunas: ARX Baltica, 2006, p. 88.

${ }^{106}$ SSD, 19210420,82 pos., p. 27.

${ }^{107}$ Jokubauskas V., min. veik., p. 115.

108 Žr.: Vaičenonis J., Lietuvos kariuomenès skaičiai 1920-1939 m. // Karo archyvas, t. 17, Vilnius, 2002, p. 151-156. 
Po 1926 m. gruodžio 17-osios perversmo abu tautininkų lyderiai prezidentu tapęs Antanas Smetona ir ministro pirmininko pareigas iki 1929 m. ejjęs A. Voldemaras - padarè tinkamas išvadas iš 1918 m. pamokų: suprato, jog be kariuomenès neišsivers, kad ši institucija turi saugoti ne tik šalies nepriklausomybę, bet ir jų asmeninę valdžią. Reikèjo tik savo rankose išlaikyti jos kontrolę. Tai padaryti pavyko taikant apgalvotą kadrų politiką ir socialines paskatas. Karininkija, kaip ir valdininkija, tapo pagrindine režimo atrama, mainais už lojalumą ígijusia ganėtinai privilegijuotą statusą ${ }^{109}$. Lietuvos karininkų algos buvo didesnès nei kaimyninèse šalyse, o ir iš krašto apsaugai skiriamų valstybės biudžeto lèšų ketvirtojo dešimtmečio pirmoje pusèje personalo išlaikymui ir gerovei tekdavo gerokai daugiau nei ginklams issigyti ${ }^{110}$. Nepaisant to, tuo metu oficialiojoje retorikoje èmè vis labiau stiprèti karinè - patriotinė gaida, atliepusi siekius konsoliduoti ir kariškai organizuoti visuomenę. Kaip ir dera autoritarinėse šalyse, tokią vidaus politikos liniją turejo palaiminti aukščiausioji valdžia. „Tautos vadu“ tituluojamas prezidentas A. Smetona savo poziciją šiuo klausimu viešai išsakè ne kartą. $1934 \mathrm{~m}$. VDU studentų korporacijos „Ramovë“ šventeje jis kalbèjo: „Šią valandą yra karo pavojus visur, ir jis eina kasdien didyn. Visos tautos ruošiasi ji tinkamai pasitikti: ginkluojasi ir kariškai aukleja jaunimą. Štai Italija ir Vokia [Vokietija - M. K.] yra sumilitarizavusios visą priaugantị jaunimą, o Lenkija tam tikru instatymu ima ginklo pajegos talkon ne tik vyrus, bet ir moteris. Šiais kraštais seka ir kiti. Tokiu būdu ištikus karui, grumsis ne tik kariuomenès, bet ir tautos. Štai kodèl svarbu šiandien visuotinis karinis auklejimas, kariškas paruošimas. “111 Kita proga jis taip pat aiškino, jog „tik neišmanèliai arba piktos valios žmonès gali teigti, kad ginklo pajèga paimanti iš valstybès iždo daug lèšu ir nieko gero jai neduodanti. Jeigu

\footnotetext{
${ }^{109}$ Truska L., Kritiškas žvilgsnis ị mūsų kariuomenès praeitị // Tautinis atgimimas ir istorija, Vilnius: Edukologija, 2012, p. 74-78.

${ }^{110}$ Jokubauskas V., min. veik., p. 127.

${ }^{111}$ Valstybès prezidento kalba metinèje Ramovès korporacijos šventèje spalių $21 \mathrm{~d}$. // Lietuvos aidas, 193410 22, p. 1. Lietuvos spauda karinio jaunimo rengimo temai užsienyje skyrè nemažai dėmesio. Žr. pvz.: Balčiūnas J., Prieškarinis jaunimo parengimas // Lietuvos aidas, 192907 29, p. 6; Juškys B., Jaunuomenès karinis rengimas svetur (Prancūzija, Lenkija, Čekoslovakija, Latvija, Estija, Suomija, SSRS, Vokietija, Italija, Anglija, JAV, Japonija), Kaunas: Sakalas, 1938.
} 
tai būtų tiesa, tai kam dabar visos šalys suskato skubotai ginkluotis?"112

Ši leitmotyvą greitai perèmè visa oficialioji spauda. Vienas po kito ivvairiuose leidiniuose ėmè rastis straipsnių, kuriuose pabrèžta būtinybẻ skleisti visuomenėje kariškas vertybes, stiprinti „moralinius ginklus“, ruoštis krašto gynybai. Po poros metų kitoje žiniasklaidos plačiai išgarsintoje kalboje A. Smetona karinị visuomenès rengimą tiesiogiai susiejo su jos organizuotumu ir drausmingumu ${ }^{113}$. Pastaraji savo kalbose ir raštuose „Tautos vadas“ dažnai vadindavo „susiklausymu“, iš esmès jam priskirdamas žodžio „paklusnumas“ reikšmę.

Rengiant Lietuvos piliečius kovai už šalies nepriklausomybę, XX a. trečiajame dešimtmetyje didžiausią reikšmę turèjo 21 metų sulaukusių vyrų terminuota privalomoji karo tarnyba ir Šaulių sajjungos veikla. Ilgainiui tuo neapsiribota - nuspręsta ne tik stiprinti jau egzistuojančią sistemą, bet ir ją plèsti. Vienas pirmųjų svarbesnių žingsnių jaunosios kartos militarizavimo kryptimi buvo karinio rengimo pamokų moksleiviams įvedimas 1929 m. ${ }^{114}$ Panašūs užsièmimai numatyti ir aukštųjų mokyklų studentijai ${ }^{115}$. Tačiau patriotiškai nusiteikęs akademinis jaunimas ir pats rode iniciatyvą spartinti ši procesą, suteikti jam solidesnị kultūrinị ir intelektualinị turinị. Ṣ̌ tikslą išsikèlè $1931 \mathrm{~m}$. įsteigta Vytauto Didžiojo universiteto studentų atsargos karininkų korporacija „Ramove“"116. Ilgametis universi-

112 Valstybès Prezidentas kariuomenès ir visuomenès susiartinimo dienos proga „Lietuvos aidui“ rašo // Lietuvos aidas, 193505 25, p. 1.

${ }^{113}$ Autoritarizmo ir karinio pasirengimo neatskiriamą jungtị, kaip valstybès egzistencijos garantą, A. Smetona subtiliai suformulavo taip: „Kai tauta drausmingai išauklèta, tai kiti vengia jos liesti, nes žino, kad atspari. O kai trūksta jai drausmès, tai bet kas jos kèsinasi.“ [Todèl] „norint tautai būti laisvai, reikia jai būti ginkluotai ir drausmingai auklètai“. Žr.: Be drausmès tauta ne tauta. Valstybès prezidento Antano Smetonos kalba, pasakyta rugsèjo 15 d. per iškilmingus pietus XII aspirantų laidos proga // Lietuvos aidas, 193709 17, p. 5.

${ }^{114}$ Ažubalis A., Kazlauskaitė -Markelienė R., Žilènienė V., min. veik., p. 8.

${ }^{115}$ Klemenčiūnas A., Mūsų universitete tikrai galimas kariškas rengimas // Karys, 1934, Nr. 1, p. 13; Studentai prašo kariškų mokslų universitete // Lietuvos aidas, 193511 25, p. 5; J. K. B. [J. K. Beleckas], Universitete bus privalomas krašto gynimo ir apsaugos kursas. V. D. Universiteto etatų pakeitimo projektas perduotas komisijai // Lietuvos aidas, 193710 29, p. 4; Ganda K. P., Karinio rengimo paskaitas universitete pradejus // Lietuvos aidas, 193810 06, p. 3.

${ }^{116}$ Liaugminas A., Militarizmas ar tautiškumas // Vairas, 1933, Nr. 12, p. 472; Plačiau apie korporacijos tolesnę veiklą šia kryptimi: Krašto karinimo reikalu // Lietuvos aidas, 193501 10, p. 2; Stud. Ats. Kar. „Ramovès“ korp. Kariškos propagandos komisija // Lietu- 
teto rektorius Mykolas Romeris teigiamai vertino kariuomenès vaidmeni patriotiškai auklejjant piliečius, mokant ginti bendrus interesus ${ }^{117}$.

Kariniam Lietuvos jaunimo rengimui svariai pasitarnavo šalies sporto reikalų suvalstybinimas. Ne tik dèl to, kad fizinis lavinimas padeda geriau pasirengti karo tarnybai, bet ir dèl to, kad sportas - savotiškas karo pakaitalas, o varžybų aistros, kaip ir karo išgyvenimai bei su jais susiję pasiaukojimo vaizdiniai, tampa konsoliduojančia atmintimi, stiprinančia nacionalinị identitetą ${ }^{118}$. Apskritai tuo metu beveik visuotinai, ypač nedemokratinèse šalyse, $\mathfrak{x}$ visuomenès sveikatos ir demografijos rodiklius buvo žvelgiama grynai per kariuomenès interesų prizmę - kuo populiacija gausesnè, jaunesnè ir sveikesnè - tuo valstybès žmogiškasis karinis potencialas galingesnis.

1932 m. Kaune buvo ìsteigti Kūno kultūros rūmai, o po dvejų metų prie jų - Aukštieji kūno kultūros kursai, kurie šalies bendrojo lavinimo mokykloms turèjo ruošti ne tik fizinio lavinimo, bet ir karinio rengimo mokytojus ${ }^{119}$. $1934 \mathrm{~m}$. pradètoje ir plačiai išgarsintoje Kūno kultūros rūmų sporto talkoje, kuri to meto žiniasklaidoje mirgejo sutrumpintu „Sporūtos“ pavadinimu, nevengta akcentuoti jos reikšmès kariams būtinų savybių ir igūdžių stiprinimui. Vienas ryškesnių to požymių - ypatingas dèmesys priešcheminès apsaugos pratyboms ${ }^{120}$. Jojimo sportą taip pat pasistengta pritaikyti kavalerijos poreikiams ${ }^{121}$. Pragmatiškas kūno kultūros pamokų pritaikymas kariniam jaunimo rengimui daugelyje Europos valstybių (ypač imperinėse) buvo praktikuojamas nuo XIX a. pabaigos ${ }^{122}$, tar-

vos aidas, 193512 06, p. 5; Alkis M., Romuviečiams ị penktus metus žengiant // Lietuvos aidas, 19361025 , p. 3.

${ }^{117}$ Dilis, Akademinè jaunuomenè petys petin su kariuomene. V. D. Universiteto studentijos kariuomenès šventès minèjimas // Lietuvos aidas, 193611 23, p. 8.

${ }^{118}$ Mangan J. A., Prologue: Combative Sports and Combative Societies //Militarism, Sport, Europe: War Without Weapons, ed. J. A. Mangan, London: Frank Cass Publishers, 2003, p. 1-2.

${ }^{119}$ Ažubalis A., Kazlauskaitė-Markelienė R., Žilènienė V., min. veik., p. 11.

120 Žr.: Žvirènas M., Priešcheminè apsauga // Sporūta: Kūno kultūros rūmų sporto talka, red. A. Jurgelionis, Kaunas: LR švietimo ministerijos Kūno kultūros rūmai, 1933, p. 286-302.

${ }^{121}$ Jo. Leo., Lietuviai ant žirgų! Sporūtos raitininkų sulèkimams pasirengta visoje Lietuvoje. Apskričių raitininkų sulèkimuose gausus dalyvių skaičius // Lietuvos aidas, 193310 05, p. 7.

${ }^{122}$ Karinis rengimas Didžiosios Britanijos bendrojo lavinimo mokyklose tapo norma 1870-1875 m. Panašiai buvo ir kitose Europos šalyse. Plačiau žr.: Mangan J. A., Ndee 
pukariu ši tendencija tik dar labiau sustiprèjo. Karišką potekstę turejjo ir ìvairūs amžių sandūroje gimę ir vèliau sẻkmingai plètojęsi atletikos judèjimai, tokie kaip čekų „Sokol“, labai imponavęs patriotiškai nusiteikusiems lietuvių sporto entuziastams ${ }^{123}$. Taip pat palankiai žiūrèta ir ị skautiją ${ }^{124}-$ ji nuo $1930 \mathrm{~m}$. tapo pagrindine oficialia mokyklinio jaunimo organizacija ${ }^{125}$. 1935-ieji tapo svarbiu atskaitos tašku, žymèjusiu nuoseklios, kryptingos Lietuvos visuomenès militarizacijos politikos pradžią. Iki tol daugiau kalbèta apie idejjas, vizijas, o praktinių žingsnių žengta mažai. Naujasis etapas prasidejjo viešai paskelbtu siekiu „sukarinti“ šalies piliečius, suformuoti glaudų ryši tarp jų ir ginkluotųjų pajègų. Neapsiribota vien jaunimu ir vyrais - tam tikras karinis rengimas numatytas ir moterims ${ }^{126}$. Kariškų akcentų viešojoje erdvèje akivaizdžiai padaugèjo. Tokị foną kūrè ne vien tikrosios tarnybos kariai ar 1935 m. ̣̇ KAM sistemą visiškai integruoti šauliai, bet ir jaunalietuviai. Tarp pastarųjų ir atitinkamų sukarintų fašistinių Italijos jaunimo formuočių būta panašumų - dèl uniformos, saliutavimo pakelta i viršų ranka ir pan. (nors to nenorèta pripažinti) ${ }^{127}$. Kita vertus tokia „mada“ tuo metu vyravo visose autoritarinèse Vidurio ir Rytų Euro-

H. S., Military Drill - Rather More than Brief and Basic: English Elementary Schools and English Militarism // Militarism, Sport, Europe: War Without Weapons, ed. J. A. Mangan, London: Frank Cass Publishers, 2003, p. 75-87, 169-183. Atskirai norètųsi išryškinti Turkijos atveji. Jis unikalus tuo, kad šioje šalyje $1926 \mathrm{~m}$. jevestas ir griežtai kontroliuojamas mokyklinio jaunimo karinio rengimo kursas (jo oficialūs pavadinimai kito) egzistuoja iki šiol. Tai tradicija, kuria siekiama ịtvirtinti turkų, kaip karių nacijos, ideologemą. Žr.: Gül Altinay A., The Myth of the Military - Nation: Militarism, Gender and Education in Turkey, New York: Palgrave MacMillan, 2004, p. 124.

${ }^{123}$ Čekų „Sokol“ ir suomių „Suojeluskunta“ - sukarinto sporto judèjimų pavyzdys, jų fizinio ir karinio lavinimo programos turèjo didžiulę ịtaką svarbiausiai Lietuvos karinei visuomeninei organizacijai - Šaulių sąjungai. Ǐssamiai apie tai žr.: Jokubauskas V., Veikti šauliškai: sportas ir karinis parengimas tarpukariu Lietuvoje // Istorija, 2015, t. 98, Nr. 2, p. 5-35. ${ }^{124}$ Jurgelevičius P., Skautų tarnyba valstybès saugumui // Mūsų žinynas, 1927, Nr. 35, p.1 193-204.

${ }^{125}$ Globys G., Skautavimas autoritarinèje Lietuvoje: išeivijos skautų refleksijos // Acta humanitarica universitatis Saulensis, t. 7, 2008, p. 62.

${ }^{126}$ Vyt. G., Karinis moterų parengimas // Lietuvos aidas, 193504 18, p. 6; J. K. Bl. [J. K. Beleckas], Greitai nustatys Lietuvos moterų karinio parengimo planą. Iš moterų karinio parengimo paskutinio susirinkimo // Lietuvos aidas, 193505 24, p. 5; Atsarginis, būsimasis karas ir studentés // Lietuvos aidas, 193804 02, p. 6.

${ }^{127}$ Jaunalietuvių sveikinimasis // Jaunoji karta, 1937, Nr. 10, p. 7. 
pos šalyse ${ }^{128}$. Tik ji buvo labiau mėgdžiojama išoriškai, nei igyvendinama doktriniškai: konservatyvūs vietos politiniai lyderiai ir tų šalių visuomenès nebuvo pasirengusios totalitariniams sąūdžiams ir tokiems socialinès inžinerijos eksperimentams, kokius tuo metu demonstravo Italija ir ypač nacionalsocialistinè Vokietija. Vis dèlto apie Italijos jaunimo karinio rengimo sistemą ${ }^{129}$ Lietuvos oficiozinèje spaudoje rašyta ne be susižavejimo ${ }^{130}$.

Skleidžiant karišką propagandą Lietuvos spaudoje, dèstant ir pagrindžiant visuomenès sukarinimo vizijas, dažniausiai pabrèžtinai vengta žodžio „militarizmas“ ${ }^{131}$. Mažų tautų atstovams jis asocijavosi su grobikišku karu, archajišku jègos kultu. Tautininkams oponavusių politinių srovių laikraščiai net ir varžomos žodžio laisvès sąlygomis visaip stengdavosi pabrěžti diktatūrinę militarizmo prigimtị. Pavyzdžiui, pagrindinis valstiečių liaudininkų dienraštis $1934 \mathrm{~m}$. publikavo straipsni „Militarizmas: atgal ị viduramžius“, kuriame labai kritiškai komentuotos visuomenès ir ypač jaunimo militarizavimo tendencijos Sovietų Sąjungoje, Vokietijoje, Italijoje ir Lenkijoje. Pasak autoriaus, „dabartiniai visų spalvų ir plauko diktatoriai teisingai pastebi, kad mūsų laikų žmogus neturi karingo patoso, pasiryžimo žudyti ir aukoti savo gyvybę. Todèl visi jie lyg susitarę svajoja išauklèti jaunime karingą dvasią. Ir kaip svajoja!“"132 Nors straipsnyje ${ }^{128}$ Vagts A., min. veik., p. 410-416, 469-473.
${ }^{129}$ Tarpukario Italijoje 6-8 m. berniukai priklausè sukarintai organizacijai „Figli della
Lupa“ („Vilkès vaikai“), 8-14 m. - marširuodavo kaip „Balillos“ nariai, 14-18 m. - pri-
klausè „Avangardui“, o $18 \mathrm{~m}$ - - tapdavo jaunaisiais fašistais ir galejo tarnauti kariuome-
neje. Plačiau žr.: Vescovi R., Children into Soldiers: Sport and Fascist Italy // Militarism,
Sport, Europe: War Without Weapons, ed. J. A. Mangan, London: Frank Cass Publishers,
2003, p. 169-190.

${ }^{130}$ Vosylius B., Karinis visuomenès auklèjimas // Mūsų žinynas, 1937, Nr. 6, p. 674-675. ${ }^{131}$ Vienoje savo viešų kalbų visos kariuomenès vardu gen. št. pulkininkas S. Raštikis aiškiai pabrèžè: „Nei aš asmeniškai, nei kiti mūsų kariai ir bendrai visi lietuviai nesame militaristai, jokių karų mes nenorime ir mūsų krašto troškimas - su visais artimesniais ir tolimesniais kaimynais gražiai ir taikingai gyventi. Tačiau iš antros pusės, kiekvieno iš mūsų šventa pareiga savo kraštą ginti nuo visų išorinių pavojų, iš kur jie tik bebūtų kilę. Prieš ginkluotą užpuolimą mes turime vartoti ginklą, nes toks gynimasis yra pateisintas visais dorovès ir moralès principais.": Jei būsime vieningi, jei turèsime stiprią ir gerai ginkluotą kariuomenę, tada Lietuvos laisvė ir nepriklausomybė bus užtikrintos. Vyriausiojo štabo viršininko gen. št. pulk. Raštikio kalba per radiją 1934 m. lapkričio mèn. 23 d. // Lietuvos aidas, 193411 26, p. 4.

${ }^{132}$ P. N., Militarizmas: Atgal ị viduramžius // Lietuvos žinios, 193410 31, p. 3. 
apie Lietuvos situaciją tiesiogiai nerašyta, daugelis teiginių bent iš dalies būtų tikę ir jai apibūdinti. Tad nenuostabu, kad kai kuriuos iš jų pašalino cenzūra, palikdama kelis tuščius teksto stulpelius laikraščio puslapiuose.

Bet radosi ir tokių autorių, kurie linko savo pažiūras deklaruoti atvirai, nesibaimindami parodyti karingumo. Tokiems imponavo Italijos fašistų lyderio B. Musolinio šūkiai, jog „militarizmas esąs tautos auklèjimo aukščiausioji forma. Militarizmas - heroizmo ir pasiryžimo pasiaukoti mokykla. Be šios bazès, be militarizmo, negali būti ir tautiškos sąmonès"133. Panašaus entuziazmo „Vairo“ puslapiuose tiesiog netvarde jauniesiems tautininkams artimas Pranas Karalius. Pasak jo, „militarizmas mažai tautai yra išsigelbejjimo veiksnys, tai būtina jos išlikimo sąlyga, tai savisaugos instinkto padiktuotas nusiteikimas" ${ }^{\text {"134 }}$. Publicistas siūlè vadovautis šūkiu „Vyrui karas - tai žaidimas“, nes „tai ir būtų mūsų senosios kovotojų tautos tradicijų garbinga tąsa“"135. O tos tradicijos, P. Karaliaus ịsitikinimu, rèmèsi vos ne spartietišku garbės imperatyvu: „Kovoje arba laimèt, arba žūt, kad nematytum pralaimejjimo.“ Jis ir kiti „Vairo“ žurnalo bendradarbiai, tokie kaip svarbiausiu radikalaus lietuviško nacionalizmo ideologu laikomas Vytautas Jakševičius-Alantas, norèjo tautą matyti dinamišką, veržlią, t. y. „žygiuojančią“ - atsisakiusią baudžiauninkiško romumo ir baimingu$\mathrm{mo}^{136}$. Suprantama, kad ị pacifizmą jie žvelgè su panieka.

Vis dèlto viešumoje tada kur kas svaresnis buvo ne isteriškas politikuojančių literatų radikalų, bet ramus racionalaus gynybinio militarizmo šalininkų - autoritetingų, viešo kalbẻjimo nevengusių Lietuvos karininkų balsas. Tiesa, jie patys savęs militaristais dèl minètos prastos šio žodžio reputacijos nevadino, bet, objektyviai žvelgiant, jis jiems apibūdinti tiktų visų pirma dèl požiūrio ị šalies gynybą ir tam tikro karinio lobizmo. Absoliuti dauguma kariškoje ir kitoje spaudoje savo įžvalgomis su visuomene besidalinančių ịvairaus rango karininkų pabrèždavo, jog karas lydi žmoniją nuo pat jos atsiradimo, tad naivu tikètis, kad šis atgrasus reiškinys staiga ims ir išnyks. Raginta ruoštis tokiam išbandymui, nes vien tik moraliniai argumentai priešo nesustabdys.

„Mūsų tarptautinè situacija mažiausiai pareina nuo mūsų pačių noro

\footnotetext{
133 Ten pat, p. 3.

${ }^{134}$ Karalius Pr., Kovojančios tautos mokykla // Vairas, 1936, Nr. 5, p. 557.

135 Ten pat, p. 556.

136 Žr.: Alantas V., Žygiuojanti tauta, Kaunas: Pažanga, 1940.
} 
taikiai su visais sugyventi, - pagrịstai tvirtino plk. Juozas Lanskoronskis. - Ji iki didžiausio laipsnio yra sąlygojama santykiais, kurie yra ar gali susidaryti tarp mūsų didžiųjų kaimynų“, nes „didžiųjų tautų susidūrime mažosios tautos ir prieš jų norą gali būti ịveltos ị bendrą sūkurị. " 137 Todèl tvirtinta, kad tokiai nedidelei, galingesnių priešiškų kaimynių supamai valstybei kaip Lietuva nuo pat mažens reikètų ruošti jaunimą tẻvynės gynybai ${ }^{138}$. Spaudoje pasitaikydavo ir raginimų net „priešmokyklinio amžiaus jaunimui skiepyti karingumas ir pasiaukojimas pasakomis ir paveiksliukais“, <...> pamokyti gražių melodijų, kariškų dainelių“. Siūlyta „didžiųjų švenčių, vardinių ar gimimo dienų progomis <...> nupirkti vaikui ne lèliukę, bet šautuvą, pistoletą, karduką, aliuminių kareivèlių ir kt., kas keltų ir ugdytų kūdikio sieloje karingumą "139. Tam, suprasdamos padèties rimtumą, pritardavo net ir kai kurios visuomenininkès ${ }^{140}$, nors Lietuvos moterų judejimas šalyje atliko tarptautiniais ryšiais susisaisčiusio oficialaus taikos idejos ir kitų humanistinių vertybių propaguotojo misiją. Bet alternatyvus, ị oficialius rèmus neịtrauktas viešai demonstruojamas pacifistinis nusiteikimas, jei ir buvo toleruojamas, tai laikytas

${ }^{137}$ Lanskoronskis J., Tautos Nepriklausomybe ir kariuomenè // Lietuvos aidas, 19330215 , p. 5.

138 Žr. pvz.: Narušis S., Karinis visuomenès rengimas // Židinys, 1935, Nr. 7, t. 22, p. 27; Naučikas K., Karinimo linkme... // Lietuvos aidas, 193503 01, p. 5; J. Zv., Pasikalbėjimas su atsargos gen. Ladyga // XX amžius, 193612 23, p. 12; Kovas visada laimejjo tie, kurie ruošèsi ir kovojo, o ne tie, kurie su baime galvojo apie žlugimą. Kariuomenès vado gen. št. pulkininko Raštikio kalba, vakar pasakyta per radiją // Rytinis Lietuvos aidas, 193611 24, p. 1; Šova A., Tautos karinis rengimasis ir kultūra //Lietuvos aidas, 193811 08, p. 9; Bulvičius V., min. veik., p. 10.

${ }^{139}$ Dielininkaitis P., Kariškoji propaganda, Kardas, 193509 15, Nr. 18, p. 383. Tuometineje Italijoje tokios vizijos jau buvo tapusios realybe: „[F]ašistinès Romos žaislų krautuvès užverstos kariškais „ginklais“: lèktuvais, tankais, patrankomis, šautuvais, kardais. Šie „ginklai gana pigūs, prieinami ir plačiajai publikai: už 2-3 litus, mūsų pinigais skaitant, čia galima nusipirkti motoru aprūpintą lèktuvą ar tanką“. „Gatvėse, aikštėse čia tolydžio sutinki pipiriukų su šautuvuku ant pečių ar su karduku prie šono. Kai mažieji Romos piliečiai žaidimo aikšteleje važinejjasi vaikiškais dviračiais ar automobiliukais, dažniausiai irgi esti „ginkluoti“. Proletarų vaikai, kurie neišgali nusipirkti tikrųjų „ginklų“, susiranda kur nors pagaliuką, lentukę ir taip vaikosi vienas paskui kitą murzini, sušilę, - ịsivaizduodami esą romėnų kariai, kovoją su skydu ir durklu. “ Žr.: V. K-nas, Žaislų vitrinose pasižvalgius. Militarinè dvasia: vyrauja karo ginklai (Mūsų korespondento Romoje) // Lietuvos aidas, 193801 26, p. 3.

140 Česnavičienė K., Kariškos dvasios auklejimas // Lietuvos aidas, 193612 14, p. 4. 
trumparegišku, nepatriotišku ${ }^{141}$. Tokią nuomonę stengtasi formuoti ir visuomenèje. Neatsitiktinai nuostata išsklaidyti „pacifistų svajones ir melagystes" kaip atskiras punktas figūravo ir 1935 m. patvirtintame Kariškos propagandos spaudoje plane ${ }^{142}$. Taigi viešojoje erdvèje antikarinés idejos buvo nuosekliai marginalizuojamos, jos nepajègè konkuruoti su oficialiai plačiai propaguojamomis karinèmis - patriotinèmis nuostatomis.

\section{BRĘSTANČIO KARO ATMOSFERA IR PACIFISTINIO BEJĖGIŠKUMO PAGUNDOS}

Negalima suprasti ir paaiškinti Lietuvos viešojoje erdveje XX a. 3-4 dešimtmetyje vyravusio požiūrio ị pacifizmą, neatsižvelgus ị to meto visuomenès saugumo pojūtị, t. y. nepasidomejjus, kiek ją trikdè nuolatinis virš Lietuvos ir visos Europos „pakibęs“ karo pavojus. Suprantama, šiuo atveju tas ịvertinimas tegali būti hipotetinis, grindžiamas negausiomis ir nelabai reprezentatyviomis užuominomis šaltiniuose, nes kitų statistiškai „pasveriamų“ duomenų iš esmès nèra. Šalies gyventojų nuotaikas tada ganètinai veikè žiniasklaida - ne tik radijas, bet ir spausdinta periodika. Tiesa, dèl cenzūros ir oficiozinių leidinių provyriausybinès redakcinès politikos ịvykiai ir procesai buvo komentuojami kiek tendencingai. Vis dèlto ir remiantis tokia medžiaga galima susidaryti šiokị tokị vaizdą mus dominančiu klausimu. Toks ir yra šio skyriaus siekis.

Perspejjimų apie netolimoje ateityje kilsianti pasaulinị karą pagrindiniuose Lietuvos dienraščiuose ir specialioje kariškoje spaudoje èmé rastis maždaug nuo XX a. trečiojo dešimtmečio vidurio ${ }^{143}$. Iki tol, nors

${ }^{141}$ Vienoje publikacijoje B. Vosylius aiškino: „Šiuo metu, kada daug siauros pasaulěžiūros žmonių, nesuprasdami gyvenimo tikrovės ir pasaulinès politikos būklès, kariuomenę laiko atgyvenusiu organizmu, sukurtu esą tik tam, kad keltų tarptautinius nesusipratimus ir lietų kraują, kada jie nori visiško kariuomenès sunaikinimo, geros valios žmonès ir tikri patriotai - savo tėvynės laisvės brangintojai kariuomeneje mato žmonių moralès išsigelbejjimą ir aukščiausių idealų igyvendinimą. "Žr.: Vosylius B., Karinis visuomenès auklèjimas // Mūsǔ žinynas, 1937, Nr. 6, p. 680.

1421936 m. kovo mèn. Kariškos propagandos spaudoje plano nuorašas // Lietuvos centrinis valstybès archyvas (toliau - LCVA), f. 509, ap.1, b. 312, 1. 20.

${ }^{143}$ Žr. pvz.: Tauta ir kariuomenè // Lietuva, 192312 30, p. 2; A. T., Tautos apsigynimo 
šalies saugumo situacija ir buvo gana pavojinga, stengtasi pasiguosti tuo, jog Tautų Sąjunga bus pajejgi sustabdyti nedidelius lokalius karus ir išlaikyti stabilumą Europoje. Bet juo toliau, tuo labiau viltys, kad augančios tarptautinès įtampos atslūgs, menko ${ }^{144}$. „Tautų santykiai šiuo metu kaip liūnai, - $1933 \mathrm{~m}$. viešoje kalboje pripažino prezidentas A. Smetona, - visur linksi, nieko tikro nèra. Oras tvankus, gali kilti audrų. "145 Tai buvo, rodos, pirmas tokiu giliu pesimizmu persmelktas viešas valstybès vadovo pareiškimas. Nerami nuotaika palaipsniui vis labiau skverbèsi i laikraščių puslapius. „Milžiniškas juodas karo šešèlis pakibo virš pasaulio ir stovi ties juo šiurpiu fantomu, kankindamas vaizduotę, slègdamas visus šviesesnius gyvenimo reiškinius" ${ }^{\text {"146 }}$, - 1935-aisiais vaizdingai konstatuota viename savaitraštyje. Kad prošvaisčių maža, rodè ir faktas, jog tais metais neatsirado asmenybès, kuri būtų pripažinta verta Nobelio taikos premijos $^{147}$. Nenuostabu, kad taip viskam klostantis dar po metų Lietuvos kariuomenès vadas brg. gen. S. Raštikis jau nebeieškojo įmantresnių retorinių formų grèsmei apibūdinti: „Pasaulis serga naujojo karo baimès liga ir serga ne be pagrindo. Kalbama ir rašoma apie karą. Tveriamos naujos totalinio, viską naikinančio, staigaus ir kitoniško karo teorijos. Visur kalami nauji ginklai. Žodis „karas“ pasidarè jau ne naujiena, nes jis visur ir beveik visų lūpose. Tai yra nedžiuginantis reiškinys. " ${ }^{148}$ Viltị, kad žmonija gali rasti kitų būdų tarpusavio prieštaravimams išspręsti, gniuždè akivaizdūs faktai: per beveik du dešimtmečius po Didžiojo karo pasaulyje įvyko 25 lokaliniai ginkluoti konfliktai, iš jų net 16 - Europo-

reikalu // Lietuva, 192409 18, p. 1; Politinè apžvalga // Lietuva, 192801 03, p. 1; Baubliauskas J., Dèl nuodingų dujų // Mūsų žinynas, 1926, Nr. 33, p. 479; Stebūnas Z., Ar bus vèl Pasaulinis karas // Diena, 192910 06, p. 3.

${ }^{144}$ Kaip pasaulis ginkluojasi. Kada bus nauja pasaulinė katastrofa // XX amžius, 193610 05, p. 5.

${ }^{145}$ Valstybès Prezidento kalba prie Laisvès paminklo lapkričio 23 d. // Lietuvos aidas, 19331125 , p. 1.

146 Šiemet karo nebus. Astrologai garantuoja už 1935 m. // Idomus mūsų momentas, 193506 09, p. 3.

147 Tarp dinamito ir taikos // Lietuvos žinios, 193511 23, p. 4.

${ }^{148}$ Kovas visada laimejo tie, kurie ruošèsi ir kovojo, o ne tie, kurie su baime galvojo apie žlugimą. Kariuomenès vado gen. št. pulkininko Raštikio kalba, vakar pasakyta per radiją // Rytinis Lietuvos aidas, 193611 24, p. 1. 
$\mathrm{je}^{149}$. Taip pat buvo pabrèžiama, kad „visur karo reikalams skiriami milijonai ir milijardai, visur karo reikalai dominuoja. Šitas kariškas drugys visumoje nèra kraujo troškimas, o tik noras sudaryti kuo didžiausią atsparą, noras atgrasinti kraujo trokštančius, kurių, deja, pasaulyje dar ir šiuo metu yra" ${ }^{150}$. Taigi XX a. ketvirtojo dešimtmečio pabaigoje Lietuvos žiniasklaidoje, gana plačiai besiremiančioje užsienio spaudos medžiaga, jau net nebebandyta kurti iliuzijų, kad naujo pasaulinio karo žmonijai kaip nors pavyks išvengti ${ }^{151}$. Visuomenè savotiškai buvo pratinama prie minties, jog gana greitai teks pažvelgti ị akis lemčiai. Tokia akistata gali sukelti ryžtą arba paniką. Norą priešintis dažnai sugniuždo išgąstis, atsiradęs įvertinus potencialių priešininkų galią, ịsivaizdavus mūšių žiaurumą, nuostolius. Tuometeje Lietuvos spaudoje gana dažnai svarstyta, koks bus būsimojo karo pobūdis ir trukmè $\dot{e}^{152}$. Naujasis pasaulinis konfliktas dažniausiai „pieštas“ remiantis praejusiojo patirtimi, tik kone vieningai tvirtinant, jog šis būsiąs dar didesnis ir siaubingesnis. Vienas baisiausių jo akcentų turèjo būti cheminio ir kitų masinio naikinimo ginklų panaudojimas. Publikacijos šia tema tiek kariškoje, tiek „geltonojoje“ Lietuvos spaudoje rèžte rèžè akị ${ }^{153}$. Bulvarinių laikraščių straipsnių turinys savotiškai apsipratusią su nuolatine karo grèsme ir net gebančią ta tema juokauti visuomenę (tai rodo karikatūros laikraščiuose - ir ne vien satyriniuose),

\footnotetext{
${ }^{149}$ D., 25 karai per paskutinius 19 metų // Lietuvos aidas, 193712 31, p. 2.

${ }^{150}$ Ginklo garbei // Lietuvos aidas, 193605 16, p. 4.

151 Žr. pvz.: Pakalnis A., Ar jau karo išvakarès // XX amžius, 193809 27, p. 3; Duff Cooper A., Antras Pasaulinis karas // Lietuvos aidas, 193907 05, p. 4.
}

152 Šepetys J., Mintys dèl būsimojo karo ilgumo // Mūsų žinynas, 1938, Nr. 5, p. 800-802; Dabartiniai karo patyrimai ir ateities karas // XX amžius, 193802 03, p. 3.

153 Žr. pvz.: Ed. Ka, Ateities dujų karas // Lietuvos aidas, 193012 05, p. 4; Bakteriologinis karas. Būsimojo karo baisumai ir perspektyvos // Lietuvos žinios, 193309 03, p. 3; Iš „D.N. W“. Elektrinis karas. Būsimojo karo baisumai ir perspektyvos // Lietuvos žinios, 193309 07, p. 3; Kazys, Artimiausių dienų karo baisenybės. Chemija ir mikrobai - žmonių masès naikintojai // Sekmadienis, 193310 01, p. 4; Artileristas, Mes ir būsimasis karas. Svarbesnès karo cheminès medžiagos ir jų ypatybès // Sekmadienis, 193311 05, p. 5; Artileristas, Mes ir būsimasis karas, Ką veiksim, kai mus nuodys // Sekmadienis, 193311 12, p. 5; P. K., Mirties spindulių karas. Būsimojo karo baisumai // Lietuvos žinios, 193403 22, p. 3; Dujų karo išvakarèse // Sekmadienis, 193701 31, p. 8; Bakteriologinis karas. Mikrobinis karas galimas? Kaip bacilinis karas vyks // Lietuvos aidas, 193802 23, p. 2; Man verčiau dujos... // Lietuvos aidas, 193911 06, p. 8; K-as, Kaip vyks rytojaus karas? // Lietuvos žinios, 193901 02, p. 2. 
kai kada vis tiek šiurpindavo. Štai kokią „gerąją naujieną“ 1933 m. Kalèdų proga rašiniu, pavadintu „Dujos!.. Dujos!“, skaitytojams perdavė populiarus Šiauliuose leistas savaitraštis „İdomus mūsų momentas“: „Praejjo laikai, kuomet priešingų kariuomenių susitikimas išsispręsdavo dvikova tarp tų kariuomenių vadų. Bet būsimajame kare, be armijų, bus priversti dalyvauti visi be išimties krašto gyventojai, seneliai, moterys, vaikai! Būsimajame kare užfrontès nebus. Visur bus frontas. Karo charakterị dabar pakeitè karo technikos išsivystymas, o daugiausia aviacija ir chemija. Šių laikų orlaivis gali labai toli prasiskverbti užfrontèn ir per kelias sekundes su savo toninėm ardomom, uždegamom ir dujinèm bombom išžudyti tūkstančius ramių gyventojų, sunaikinti pramonès centrus ir t. t. "154

Toks „karinis parengimas“ jautresnių nervų žmones, tikètina, galejo pastūmèti ị neviltị ar isteriją, bet ne ịkvėpti ryžtą kovoti, atsispirti negandoms. Nenuostabu, kad ilgainiui informaciją apie būsimąjị karą, ginkluotès technologijas spaudoje imta redaguoti atsakingiau, vengiant siaubą keliančių realistinių detalių. Oficioziniuose laikraščiuose netgi atsirado raminančių straipsnių, kuriuose aiškinta, kad cheminis ginklas nèra jau toks baisus, kad jau išrasta gana efektyvių apsaugos priemonių ${ }^{155}$. Apskritai tuo metu visuomenę bandyta padrąsinti samprotavimais arba įrodinèjimais, jog net ir didžiausius sunkumus galima ištverti, per baisiausius konfliktus išgyventi - tereikia tik tam pasiruošti, tinkamai morališkai nusiteikti - nepasiduoti panikai ir kapituliacinėms nuotaikoms. Aiškinta, jog net tokia maža valstybė kaip Lietuva, susitelkusi, pakankamai apsiginklavusi, sumaniai veikdama, gali duoti rimtą atkirtị kur kas didesniam agresoriui („ežys mažas, bet didžiausiam šuniui neįveikiamas“) ${ }^{156}$.

Teisininkas Martynas Kavolis ił pasirengimo gynybai procesą kvietė pažvelgti kiek netipiškai. Jis aiškino taip: „Tuo tarpu, kai kariavimas turi savo blogas puses, ruošimasis karui tautai neduoda užmigti ir pasenti. Jis verčia gerai susitvarkyti viduje, jis reikalauja tautos politinio subrendimo ir vienybės, jis skatina fiziškajji ir psichiškajj tautos sveikatingumą. Todèl ir mes turime taip pat išnaudoti karinio pasiruošimo gerąsias ypatybes. Kitaip atsiliktume kultūrinėse tautų varžytinèse. Jei karas ir galètų apvilti, tinkamas ruošimasis prie karo blogo neatneš. Tačiau ši ruošimąsi

\footnotetext{
${ }^{154}$ B. N., Dujos!.. Dujos! // Idomus mūsu momentas, 193312 25, p. 6.

155 Žr. pvz.: Ar ne per daug įsibauginta dujų? // Lietuvos aidas, 193608 11, p. 7.

${ }^{156}$ Neveravičius F., Tikroji tautos jèga // Lietuvos aidas, 193503 21, p. 6.
} 
kariauti mes tesuprantame tik kaipo priemonę tobulintis individualiai ir kolektyviai bei apsiginti, o ne užkariauti. “157

Dažnai ir gana atvirai apie karinio pasirengimo ir nusiteikimo svarbą viešumoje įžvalgomis pasidalydavo kariuomenès vadas brg. gen. S. Raštikis. Dar prieš užimdamas šias pareigas 1934 m., jis, primindamas neseną praeiti, dèstè: „Ginkluota jèga iki šiol dar yra ir be jokių abejonių dar ilgai bus vienu iš svarbiausių tautos laisvès pagrindų. Juk kiekvienam iš mūsų dabar yra visiškai aišku, kas iš mūsų šiandien būtų buvę, jei prieš 16 metų nebūtumèm padarę griežtų žygių savo kariuomenei suburti. Atsakymas aiškus: jei neturètume savo kariuomenès, tai turbūt neturètume ir savo nepriklausomos Lietuvos. ${ }^{158}$ Dèl to, - tęsé savo mintị jis, - „<...>jei norime likti laisvi ir nepriklausomi, neturime užmiršti savo apsaugos ir turime būti gerai pasirengę gintis. Nejaugi mes, būdami ypatingoje geografiškoje padètyje ir matydami kitų ginklavimąsi ir rengimąsi karui, būsime kaip anie kiškiai, gyvatès užhipnotizuoti, t. y. tupèsime, drebèsime ir nieko nedarysime? Ne, to nebus, nes to norètų mūsų priešai, bet ne mes patys sau. Nieko svetimo mes nenorime, nieko mes nepulsime, bet gali būti, kad mūsų kraštas, kaip maža valstybẻ, visiškai be mūsų noro galès būti įtrauktas ị kitų didesnių valstybių ginkluotą susiremimą. "159 Racionalios mintys, svarūs argumentai, bet, deja, netolima ateitis parodè, kad valstybės ginkluotụjų pajėgų vadovybės veiksmai ryžtingumu neprilygo žodžiams. Paradoksalu, bet Lietuva 1938-1940 m., kad ir neblogai apsiginklavusi, turinti nemenką kariškai parengtų vyrų rezervą, lemtingų išbandymų akivaizdoje pasuko pacifistiniu nuolaidų keliu, nors tokio maršruto galimybè iki tol nuolat kritikuota viešojoje erdvèje. Pasak šiuos ivvykius emigracijoje giliai ir konceptualiai apmąsčiusio poeto Jono Aisčio, lietuviai pristigo to automatinio jausmo ir ryžto, kuriuo zylè, gindama savo lizdeli, puola vanagą... ir net lokį ${ }^{160}$.

Kitas įdomus dalykas, krintantis $\mathfrak{i}$ akis tyrinejjant XX a. ketvirtojo dešimtmečio antrosios pusès lietuviškų dienraščių publikacijas apie būsimąji pasaulinị konfliktą, - tai bandymai atspèti arba „apskaičiuoti“ jo

\footnotetext{
${ }^{157}$ Kavolis M., Socialinè taikos ir karo reikšmė // Mūsų žinynas, 1937, Nr. 4, p. 405.

${ }^{158}$ Jei būsime vieningi, jei turèsime stiprią ir gerai ginkluotą kariuomenę, tada Lietuvos laisvė ir nepriklausomybẻ bus užtikrintos. Vyriausiojo štabo viršininko gen. št. pulk. Raštikio kalba per radio 1934 m. lapkričio mèn. 23 d. // Lietuvos aidas, 193411 26, p. 4. 159 Ten pat.

${ }^{160}$ Aistis J., Milfordo gatvès elegijos, London: Nida, 1968, p. 142.
} 
pradžios datą ${ }^{161}$. Iki Čekoslovakijos okupacijos dar ginčytasi dèl konkrečių metų, kada Europą apims karo liepsnos, o 1939-aisiais kalbos sukosi jau tik apie mènesius ir net dienas. Šiandieninių, šiek tiek bendrųjų XX a. istorijos žinių turinčių žmonių suvokimas apie Antrojo pasaulinio karo pradžią yra gana stereotipinis: dažnai manoma, jog nacistinė Vokietija Lenkiją užpuolè staiga, šiai to net nenujaučiant. Toks vaizdinys greičiausiai yra suformuotas tam tikros publicistikos ir iš dalies trivialesnio pobūdžio kino dokumentikos bei istoriografijos. Bet iš tiesų 1939-ųjų rugsejjo 1-oji nebuvo perkūnas iš giedro dangaus. Tuo galima ịsitikinti vien jau pavarčius tų metų didžiausių Lietuvos dienraščių vasaros pabaigos numerius. Ypač tam tinka kad ir katalikiškosios opozicijos leistas „XX amžius“. Jo straipsnių antraštès labai iškalbingos, o informacija, galima sakyti, tiesioginè - ne vien iš oficialių naujienų agentūrų komunikatų, bet ir Varšuvos gyvenimą iš arti stebejusių liudininkų korespondencijos. Jau prieš savaitę iki lemtingosios dienos laikraščio skaitytojai buvo informuojami, kad Lenkija aktyviai ruošiasi karui, gyvena karo nuotaikomis, vyksta mobilizacija, sostinès skveruose kasami apkasai, statomi priešlèktuviniai pabūklai ${ }^{162}$. Šios žinios turejjo padèti susivokti, kad visa tai daroma ne šiaip sau - numatoma ilgai brendusio konflikto atomazga.

Antrojo pasaulinio karo pradžią Lietuvos visuomenè sutiko gana sutrikusi, paskui nuotaikos èmè svyruoti. Pirmosiomis rugsẻjo dienomis

${ }^{161}$ Kai kurios prognozès buvo kone pranašiškos. Antai 1938 m. pabaigoje „Lietuvos žinios" su komentarais perspausdino žymaus Kominterno funkcionieriaus Georgijaus Dimitrovo kalbą. Jis teigè, kad Vengrija „bus puolama 1939 m. pavasarị, o Lenkija bus okupuota tų pačių metų rudenį. Rumunija ir Jugoslavija bus „sutvarkytos“ 1940 m. Prancūzija, Belgija, Olandija, Danija ir Šveicarija bus puolamos $1941 \mathrm{~m}$., karas prieš SSRS prasidès 1941 rudenį“: „D.H.“, Karas prieš SSRS prasidèsiąs 1941 m. rudenį, - sako Dimitrovas // Lietuvos žinios, 193811 10, p. 12. Taip pat žr.: Karas 1940 metais // Rytinis Lietuvos aidas, 193808 12, p. 2.

${ }^{162}$ Kaip lenkai ruošiasi karui. Kiek reikia maisto dviem savaitèms // XX amžius, 193908 25, p. 7; Sirijos Gira V., Šiandien ar rytoj? Specialus pranešimas „XX amžiui“ iš Varšuvos // ten pat, 193908 26, p. 8; Lenkija pasirengusi sumobilizuoti 4 mil. karių. Mobilizacija vykdoma gaivalingu tempu. Visoj Lenkijoj džiaugsmas dèl sutarties su Anglija pasirašymo. Telefonu iš Varšuvos // ten pat, 193908 26, p. 12; „Penkios minutès prieš karą“. Moderniškas Varšuvos randez!-vous - priešlekktuviniai apkasai. Antrasis pranešimas iš Varšuvos // ten pat, 193908 28, p. 5; Varšuva energingai ruošiasi gintis. Nutrauktas susisiekimas su Vokietija // ten pat, 193908 28, p. 5; Visuotinė mobilizacija Lenkijoje // ten pat, 193908 31, p. 4. 
Kaune jautėsi tam tikra desperacija: gyventojai puolè karštligiškai pirkti maisto produktus išgyvenimo atsargoms ir įvairias kitas pramonines, barteriniams mainams tinkamas prekes. Tačiau gana greitai, Vyriausybei raminant ir taikant tam tikras prekybos sferos policinès kontrolès priemones ${ }^{163}$, šis panikos požymių turintis sujudimas nurimo, grịžta prie ankstesnio drausmingo gyvenimo ritmo. Tikejimas įstatymais ir valstybès galimybėmis užtikrinti jų vykdymą tuo metu nesumenko. Reikia pažymèti, kad paskutiniais Lietuvos valstybingumo metais, vienas po kito įvykus dramatiškiems sukrètimams, nemaža dalis visuomenès labai palankiai vertino aukštais valstybès pareigūnais tapusius karininkus, su jais siejo viltis, kad valstybė sėkmingai pergyvens sunkų, pavojų kupiną laikotarpi. Antai vienoje $1939 \mathrm{~m}$. pavasario Valstybės saugumo policijos pažymoje apie gyventojų požiūrị i brg. gen. Jono Černiaus ${ }^{164}$ vyriausybę, kurioje, be paties premjero, buvo dar trys generolai (Kazys Musteikis, Kazys Skučas ir Jonas Sutkus), rašoma: „Ūkininkija reiškia pasitenkinimą, kad dabartinejje Ministrų taryboje vyrauja kariškiai, iš to daro išvadą, kad dabar jau jokiam priešui nebus daroma bet kokių nuolaidų. Jie ịsitikinę, kad ministrai kariškiai daug prisidès prie ūkininkų būklès pagerinimo, nes jie per ūkininkaičius kareivius puikiai pažįsta jų gyvenimą. "165 Tačiau tai - tik vienas epizodas, neleidžiantis kalbėti apie tokių nuotaikų pastovumą ir ilgalaikiškumą. Tuo laikotarpiu jos gana ryškiai svyravo. Šie pokyčiai labai priklausè nuo ịvykių tarptautinejje arenoje ir to, kaip jie paliesdavo Lietuvą. Vienu atveju šalies gyventojus apimdavo nerimas arba baimè su pacifistinio bejègiškumo atspalviu, kitais atvejais - sukildavo karingas ūpas. Pavyzdžiui, 1938 m. kovo pabaigoje, Lenkijai pateikus Lietuvai ultimatumą dèl diplomatinių santykių užmezgimo, žymi

${ }^{163}$ Plačiau žr.: Vaskela G., Lietuva 1939-1940 metais: Kursas j̨ valstybès reguliuojamą ekonomika, Vilnius: Lietuvos istorijos institutas, 2002, p. 44-54.

${ }^{164}$ Plačiau apie asmenybę ir veiklą žr.: Rudis G., Jonas Černius - vilties generolas // Lietuvos Respublikos ministrai pirmininkai (1918-1940), Vilnius: Alma litera, 1997, p. 409-425; Jankauskas V., Jonas Černius. Sąžiningai atlikęs pareigą, Nepriklausomos Lietuvos generolai, I dalis, Vilnius: Lietuvos dailès akademija, 1998, p. 216-227; Paulauskas H., Lietuvos kariuomenès brigados generolas ministras pirmininkas Jonas Černius, Vilnius: Rosma, 2006.

16519390401 Valstybės saugumo policijos (toliau - VSP) Šiaulių apygardos biuletenis // LCVA, f. 378, ap. 5, b. $4421,1.92$. 
dalis lietuvių troško duoti ryžtingą atkirtị Varšuvos grasinimams ${ }^{166}$. Tai rodo visuomenès nuotaikas stebejusių valstybės institucijų - saugumo policijos, karo komendantų, apskričių viršininkų - raportai, ataskaitos. Per nepriklausomybès dvidešimtmetị valstybès stimuliuotas antilenkiškumas neliko be pèdsako - jis, akivaizdu, bent pradiniu - emocionaliausiu - momentu užgožè karo baimę ${ }^{167}$. Visai kitokią reakciją sukèlè nacių Vokietijos spaudimas. Ryžtą jai priešintis gerokai prislopino racionaliai pasvertas karinio potencialo ir technologinio išsivystymo skirtumas. Antai po 1938-ųjų rudenị Vokietijos ịvykdyto Čekoslovakijai priklausančio Sudetų krašto atplèšimo Lietuvos kariuomenès štabo II skyriaus viršininkas plk. Kostas (Konstantinas) Dulksnys savo pažymoje konstatavo, jog „yra nemažas skaičius asmenų, tame tarpe ir karių, kurie su nepasitikejjimu ir nusivylimu žiūri ị kariuomenę. Kalbose pažymima, kad, girdi, jeigu Čekoslovakija, kuri buvo taip apsiginklavusi ir turejjo sąjungininkų, negalejo kariauti, tai Lietuvai nesą ko galvoti net apie gynimąsi. Pasak jų, dabar reikią Lietuvos kariuomenę sumažinti pusiau, o biudžeto lěšas paskirti kitoms, naudingesnėms sritims plèsti. Nesą reikalo išleisti milijonų i̇ užsienį už perkamus ginklus"168. Bet po metų, kai Vokietija, užpuldama Lenkiją, pradejjo Antrąji pasaulinị karą ir kai ị tai reaguodama Lietuvos

\footnotetext{
166 Tai iliustruojanti epizodą savo atsiminimuose yra užfiksavęs ir poetas Jonas Aistis: „1939 m. rudenị, važiuojant iš Kauno autobusu ị tèviškę [Pakaunèje - Rumšiškių km. M. K.], atsisèdo šalia puskarininkèlis ir užkalbino. Pasirodo, jis buvo gretimo kaimo vaikinas, liktinis puskarininkis, tarnavęs zenitinès artilerijos daliny. Išèjo kalba apie lenkų ultimatumą. Paaiškejo, jo dalinio nekantriai laukta karo veiksmų: pro mus būtų nepraskridęs nè vienas lèktuvas, mes būtume parodę savo šaltą kraują ir visas rupūžes ištaškę ore... Tai buvo paprastas kaimo bernelis, baigęs vien pradžios mokyklą, bet modernus kareivis, ittikęjęs technika. Esu tikras, kad jis būtų atlikęs savo pareigą geriau negu kariuomenès vadas.“: Aistis J., min. veik., p. 143. Plačiau apie lietuvių reakciją i 1938 m. Lenkijos ultimatumą žr.: Janauskas G., Jèga nèra teisè. 1938 metų Lenkijos ultimatumas ir Lietuvos visuomenè // Prievartos vaisiai: Lietuvos ir Lenkijos santykiai 1920-1940 metais, Kaunas: Vytauto Didžiojo universitetas, 2002, p. 58-61.

${ }^{167}$ Istorikas Algimantas Kasparavičius lietuvių antilenkiškumą dèl jo iracionalių bruožų, tam tikro metafiziškumo pagrịstai prilygino religijai. Žr.: Kasparavičius A., Katastrofos nuojautos: Lietuvos karinè diplomatija Antrojo pasaulinio karo išvakarèse // Karo archyvas, t. XXVII, Vilnius: Generolo Jono Žemaičio Lietuvos karo akademija, 2012, p. 263.

16819381017 Kariuomenès štabo II skyriaus viršininko plk. K. Dulksnio pažyma // $L C V A$, f. 929 , ap. 1, b. 631, 1. 56.
} 
vyriausybė paskelbė dalinę mobilizaciją ${ }^{169}$, nemažai šalies gyventojų ir karių buvo jau kitokios nuotaikos. 1939 m. rugsèjo $18 \mathrm{~d}$. Valstybės saugumo policijos Šiaulių apygardos biuletenyje konstatuota: „Karingumo ūpas, jei reikètų kariauti, yra geras. Daugelis jaunų vyrų yra pasiryžę vykti $\mathfrak{i}$ kariuomenę ir jokio nusiminimo nerodo. Kiekvieną valandą laukia mobilizacijos. “ ${ }^{170}$ Po kelių savaičių vèl pažymèta, jog „staiga pašaukus didelị kiekį atsarginių [karių], visų ūpas pakilo, nes dauguma manè, kad jie šaukiami žygiavimui atsiimti Vilniaus kraštą "i"171.

Tokie duomenys liudija per tarpukarị išaugusị lietuvių visuomenès karinị nusiteikimą, kurị vargiai galèjo pakirsti abstrakčios pacifistinès idejos. Kita vertus, tuo metu nuolat kaitusi nerimo dèl artejjančio karo atmosfera, autoritarinis „auklejimas“ tiek plačiajai Lietuvos visuomenei, tiek elitui padarè tam tikrą poveikį, pasireiškusị vidiniu sutrikimu, kai viltis ir lūkesčius keitė nusivylimas, stumiantis ị demoralizaciją, masinusią rinktis pasyvų prisitaikymą arba kraštutinumais paremtą veiklą. Šj reiškini, ko gero, prasminga pavadinti emociniu ir moraliniu „perdegimu“. Gal todèl Antrojo pasaulinio karo metais, kai vieną krašto okupaciją keitè kita, nebeturint tvirtų ir atsakingų politinių autoritetų, anksčiau suformuotos kariškos aspiracijos, pasirengimas naudoti prievartą igavo ir ne tik dinamiškų patriotinių, bet ir kraupių antihumaniškų pavidalų.

\section{IŠVADOS}

1. Antikarinès, pacifistinès, idèjos nepriklausomoje Lietuvoje (19181940 m.) daugiausia sklisdavo per periodinę ir kitokią spaudą, tačiau tai nebuvo intensyvus procesas. Oficialioji žiniasklaida tam skirdavo nedaug dėmesio, nors su tarptautinėmis taikos šalininkų organizacijomis, jų veikla, o taip pat ịvairiais pacifistinio turinio kultūros reiškiniais (literatūroje, kine ir pan.) bendrais bruožais supažindindavo. Lietuviškoji viešoji erdvè, nors ir provinciali, nebuvo atitrūkusi nuo pasaulinių realijų. Tačiau

\footnotetext{
${ }^{169}$ Išsamiau žr.: Jokubauskas V., Lietuva ant karo slenksčio: 1939 m. kariuomenès mobilizacija // Karo archyvas, t. XXVII, 2012, p. 275-332.

${ }^{170} 19381017$ Kariuomenès štabo II skyriaus viršininko plk. K. Dulksnio pažyma // LCVA, f. 929, ap. 1, b. 631, 1. 154.

${ }^{171} 19390918$ VSP Šiaulių apygardos biuletenis // LCVA, f. 378, ap. 5, b. 4421, 1. 127.
} 
ši informacija inertišką, agrarinę Lietuvos visuomenès daugumą nelabai paveikè - tą poveikị vargiai ịmanoma lyginti su situacija Vakarų Europos šalyse.

2. Tarptautines diplomatinio pobūdžio taikos šalininkų iniciatyvas sisteminé Lietuvos žiniasklaida vertino palankiai, bet $\mathfrak{i}$ vietinius pacifistus, priklausomai nuo jų ideologinès kilmès ir tikslų, žvelgè arba labai kritiškai, arba net priešiškai. Pabrežtinai stengtasi jų „nereklamuoti“, neminèti ryškesnių asmenybių. L. Tolstojaus šalininkai vadinti atitrūkusiais nuo tikrovès, legaliai veikę kairuoliškos pakraipos antikariniai inteligentų sambūriai - neatsakingais ir nepatriotiškais, o komunistai - sąmoningai kenkiančiais Lietuvai. Apskritai pacifizmas laikytas negyvenimiška ir net žalinga ideja, silpninančia valstybès savisaugos, besiremiančios krikščioniškuoju teisingo (gynybinio) karo principu, galias.

3. Didumai lietuvių visuomenès elito dar iki $1918 \mathrm{~m}$. buvo artimos antikarinès ir pacifistinès idèjos, tačiau Nepriklausomybės kovų realybè ir šalies integralumo problemos privertė nuo jų atitolti. Kiek aktyviau antikarines nuostatas Lietuvos seimuose 1920-1926 m. kèlè tik socialdemokratai. Autoritarinio režimo laikotarpiu (1927-1940 m.) kariuomenè tapo pagrindine prezidento valdžios atrama, o dèl nuolatinių išorinių pavojų valstybingumui Lietuvoje èmè stiprèti „gynybinio militarizmo“ tendencijos - pradeti rengti ir igyvendinti visuomenès sukarinimo planai. Šalies politinè vadovybè ir ịtakingi kariuomenès atstovai spaudoje piliečius nuolatos nuteikinèjo grèsmių akivaizdoje nepasiduoti pacifistinèms iliuzijoms.

4. Lietuva, kaip ir kitos Europos valstybès, XX a. trečiajame dešimtmetyje gyveno būsimo naujo pasaulinio karo nuojauta, o ketvirtajame jo laukimu. Žiniasklaidoje netrūko baimę keliančios informacijos apie tuo tikslu kuriamus galingus ginklus ir numatomus pražūtingus jų padarinius. Tačiau Lietuvos visuomenè savotiškai prisitaikè prie nuolatinio nerimo atmosferos. Nèra pakankamo pagrindo teigti, kad būsimo karo baimè labai padidino šalies piliečių imlumą pacifistinèms idejjoms - jų perspektyvumu nelabai tikèta. Per Nepriklausomybės dvidešimtmetị susiformavusi lietuvių kariška mąstysena dèl autoritarizmo poveikio stokojo savarankiškumo, pasižymejjo nuotaikų svyravimais, buvo nepakankamai atspari demoralizacijai ir radikalizmui.

Iteikta $2017 \mathrm{~m}$. spalio $25 \mathrm{~d}$. 


\title{
RÉFLEXION SUR LE PACIFISME DANS LA LITUANIE DE L'ENTRE-DEUX-GUERRES (ANNÉES 20 ET 30 DU XXE SIÈCLE)
}

\author{
Dr. Modestas KUODYS \\ Musée du Fort IX de Kaunas
}

Larticle analyse, en s'appuyant surtout sur la presse périodique et autres sources publiées, un thème encore peu étudié dans l'historiographie : la vision du pacifisme et de ces concepts dans l'espace public lituanien des années 20 et 30 du XXe siècle. Le premier des quatre chapitres de l'article décrit les échos des sentiments anti-guerres internationaux dans la vie publique lituanienne. La presse informait la société sur les représentants les plus connus des idées pacifistes, les organisations internationales de défense de la paix ou les événements culturels, tels l'adaptation du roman de E.M. Remarque " $\AA$ l'Ouest, rien de nouveau " à Hollywood en 1930. Ce film, qui a aussi intéressé de nombreux spectateurs lituaniens, a été très mal accueilli en Allemagne. Le deuxième chapitre de l'article présente les représentants des idées pacifistes et anti-guerres ainsi que leurs considérations en Lituanie. Il y a peu d'informations dans la presse sur les pacifistes lituaniens et celles-ci sont assez abstraites. On mentionnait surtout les disciples de L. Tolstoï et les groupes légaux d'intellectuels de gauche. Une assez grande attention était accordée pour démasquer les slogans de nature démagogique des communistes anti-guerres. Les idéalistes pacifistes étaient jugés avec plus d’indulgence, bien que leurs attitudes étaient qualifiées de naïves. On regardait de la manière la plus favorable les pacifistes dits pratiques qui aspiraient à réduire par des moyens diplomatiques la tension internationale. La presse lituanienne traitait de manière assez détaillée le point de vue de l'Église catholique sur la guerre. Le troisième chapitre de l'article analyse combien et comment on manipulait avec les notions du militarisme et de l'antimilitarisme dans la rhétorique politique de la Lituanie : on commente les discours des membres du Seimas, des dirigeants de l'État, des officiers supérieurs et autres personnalités publiques. Après avoir considéré le spectre des opinions qui circulaient à l'époque, on peut constater que la voix des pacifistes n'a été un peu plus audible que dans la première moitié des années 20 , et, plus tard, la propagande de la préparation militaire de la société l’a presque entièrement supplantée. L'idée s'est installée solidement que la Lituanie ne pouvait pas se fier au droit international, mais qu'elle devait être prête à se défendre par les 
armes contre déventuels agresseurs. Un tel point de vue était encouragé par une situation internationale trouble et l'émergence des contours d'une nouvelle guerre mondiale.

Il y avait un nombre assez considérable d'informations sur ce sujet dans la presse lituanienne et elles renforçaient parfois le niveau d'inquiétude de la société. Toutefois, l'appréhension d'une future guerre n'a pas eu un plus grand impact sur la propagation des sentiments pacifistes parmi les habitants de la Lituanie. 


\title{
REFLECTION OF PACIFISM IN THE INTER-WAR LITHUANIA (3RD AND 4 TH DECADES)
}

\author{
Dr. Modestas KUODYS \\ Kaunas IX Fort Museum
}

In this article, which is mainly based on periodical publications and other published sources, analysis of the almost unexplored subject of historiography is carried out focusing on the attitudes towards pacifism and its concepts in the Lithuanian public space in the 1920s and 1930s. The first of the article's four parts highlights the reflections of global anti-war moods in the public life of Lithuania. The press introduced society to the ideas of the world's most prominent pacifists, international peace-keeping organizations or cultural events such as the movie adaptation of Remarque's novel All Quiet on the Western Front by Hollywood in 1930. This film attracted a large Lithuanian audience, even if it was met in Germany with a very hostile reception. The second part of the article presents pacifists, and the authors of anti-war ideas, and how they were received in Lithuania. There is very little information about the Lithuanian pacifists in the press, and it is rather abstract. Most often followers of L. Tolstoy and communications of the legitimate leftist intellectuals were mentioned. Particular attention was paid to the demagogic anti-war communist slogans. Pacifist idealists were assumed as less harmful although their attitudes were called naive. The so-called pacifist practitioners who sought to reduce international tension by means of diplomatic means were most welcome. The Lithuanian press was also aware of the attitude of the Catholic Church to the war. The third part deals with how much and how the concepts of militarism and anti-militarism were used for manipulations in the political rhetoric of Lithuania when the statements of members of the Seimas, heads of state, senior officers, and other public figures were commented on. Having evaluated the spectrum of opinions circulating at that time, it can be stated that the voice of the pacifists in public was somewhat more pronounced only in the first half of the 1930s, and later it was almost completely overshadowed by the official propaganda of the military training of the public. The notion that Lithuania could not rely on international law but must be prepared to resist potential aggressors was firmly established. Such an attitude was inspired by the troubled international situation that emerged in relation to the perspective of the new world war.

There was quite a lot of information about this in the Lithuanian press, and at times it increased the degree of anxiety in society. However, fears about the upcoming war did not have a greater impact on the spread of pacifist moods among the population of Lithuania. 